\title{
Review \\ Development of Antibiofilm Therapeutics Strategies to Overcome Antimicrobial Drug Resistance
}

\author{
Sahaya Nadar ${ }^{1}\left(\mathbb{D}\right.$, Tabassum Khan ${ }^{2} \oplus$, Simon G. Patching ${ }^{3, *(\mathbb{C}}$ and Abdelwahab Omri ${ }^{4, *}(\mathbb{C}$ \\ 1 Department of Pharmaceutical Chemistry, St. John Institute of Pharmacy and Research, \\ Mumbai 400056, India; sahayan@sjipr.edu.in \\ 2 Department of Pharmaceutical Chemistry \& Quality Assurance, SVKM's Dr. Bhanuben Nanavati College of \\ Pharmacy, Mumbai 400056, India; tabassum.khan@bncp.ac.in \\ 3 School of Biomedical Sciences and Astbury Centre for Structural Molecular Biology, University of Leeds, \\ Leeds LS2 9JT, UK \\ 4 The Novel Drug \& Vaccine Delivery Systems Facility, Department of Chemistry and Biochemistry, \\ Laurentian University, Sudbury, ON P3E 2C6, Canada \\ * Correspondence: s.g.patching@leeds.ac.uk or simonpatching@yahoo.co.uk (S.G.P.); \\ aomri@laurentian.ca (A.O.)
}

check for updates

Citation: Nadar, S.; Khan, T.; Patching, S.G.; Omri, A. Development of Antibiofilm Therapeutics Strategies to Overcome Antimicrobial Drug Resistance. Microorganisms 2022, 10, 303. https://doi.org/10.3390/ microorganisms10020303

Academic Editors: Maja Abram and Anja Klančnik

Received: 30 December 2021

Accepted: 25 January 2022

Published: 27 January 2022

Publisher's Note: MDPI stays neutral with regard to jurisdictional claims in published maps and institutional affiliations.

Copyright: (c) 2022 by the authors. Licensee MDPI, Basel, Switzerland. This article is an open access article distributed under the terms and conditions of the Creative Commons Attribution (CC BY) license (https:// creativecommons.org/licenses/by/ $4.0 /)$.

\begin{abstract}
A biofilm is a community of stable microorganisms encapsulated in an extracellular matrix produced by themselves. Many types of microorganisms that are found on living hosts or in the environment can form biofilms. These include pathogenic bacteria that can serve as a reservoir for persistent infections, and are culpable for leading to a broad spectrum of chronic illnesses and emergence of antibiotic resistance making them difficult to be treated. The absence of biofilm-targeting antibiotics in the drug discovery pipeline indicates an unmet opportunity for designing new biofilm inhibitors as antimicrobial agents using various strategies and targeting distinct stages of biofilm formation. The strategies available to control biofilm formation include targeting the enzymes and proteins specific to the microorganism and those involved in the adhesion pathways leading to formation of resistant biofilms. This review primarily focuses on the recent strategies and advances responsible for identifying a myriad of antibiofilm agents and their mechanism of biofilm inhibition, including extracellular polymeric substance synthesis inhibitors, adhesion inhibitors, quorum sensing inhibitors, efflux pump inhibitors, and cyclic diguanylate inhibitors. Furthermore, we present the structure-activity relationships (SAR) of these agents, including recently discovered biofilm inhibitors, nature-derived bioactive scaffolds, synthetic small molecules, antimicrobial peptides, bioactive compounds isolated from fungi, non-proteinogenic amino acids and antibiotics. We hope to fuel interest and focus research efforts on the development of agents targeting the uniquely complex, physical and chemical heterogeneous biofilms through a multipronged approach and combinatorial therapeutics for a more effective control and management of biofilms across diseases.
\end{abstract}

Keywords: biofilms; infection; inhibitors; extracellular polymeric substances; antimicrobials; small molecules

\section{Introduction}

The term biofilm refers to a community of stable microorganisms encapsulated in an extracellular matrix produced by themselves that develops in a multitude of biological and ecological environments [1,2]. Microbial biofilms are of grave health concern worldwide owing to their ability to be resistant to antibiotics, resist host immune response and combat extreme environmental stress, and their association with persistent infections [3]. Morbific microbes possess the ability to form biofilms in tissues and biomaterials, inducing chronic infections that are arduous to treat [4,5]. Common bacteria that form biofilms include Pseudomonas aeruginosa [6], Staphylococcus epidermidis [7], Enterococcus faecalis [8-10], Staphylococcus aureus [11-14], Klebsiella pneumoniae [15-17], Streptococcus viridans [18-21], 
Escherichia coli [22,23], and Proteus mirabilis [24,25]. Biofilm recalcitrance [26-30] is the potential of the microbes to sustain even in high concentrations of antibiotics, which leads to recurrence of infections and collapse of treatment. The microbes enclosed within the biofilm have proven to be more resistant towards classic antibiotic therapy in contrast to the planktonic cell population. This recalcitrance is revocable by disrupting the biofilm and reinstating the microbes to the planktonic state [31]. Patients with ingrained medical devices such as prosthetic heart valves, catheters, joint prosthesis, cardiac pacemakers, dental implants and contact lenses have utmost risk of biofilm-based nosocomial infections [32-34]. Such foreign bodies provide an exemplary surface for the adhesion of bacterial cells, which can be facilitated by non-specific factors such as shear forces, hydrophobicity and electrostatic interactions [35-37].

A common example of biofilms covering abiotic surfaces is their formation on dental restorative and implant materials, where oral bacteria adhere to hydrophobic and hydrophilic abiotic surfaces and biofilms accumulate more readily on rough than on smooth surfaces $[38,39]$. This can result in periimplantitis, a destructive inflammatory process that affects the soft and hard tissues surrounding dental implants and may result in implant failure. There is a multitude of methods for decontaminating pathogenic microorganisms on dental implants [40].

Exposure of bacteria to concentrations of an antibiotic that are lower than the minimum inhibitory concentration (MIC), known as subinhibitory concentrations, can enforce a higher capacity for biofilm formation, which in turn can result in a decreased susceptibility to antibiotics [41-44]. For example, subinhibitory antibiotic concentrations have recently been shown to enhance biofilm formation of clinical Enterococcus faecalis isolates [45]. The subinhibitory concentration may be introduced by improper dosing of an antibiotic or could be created in difficult to reach local regions such as in a dental root canal. The inability of antibiotic treatments to eliminate bacterial biofilms at subinhibitory concentrations has hastened the quest for new antibiofilm agents and strategies. In this review we therefore look at how biofilms are formed and how this process could be inhibited, then consider possible antibiofilm agents and strategies in the quest to overcome antimicrobial drug resistance.

\section{Biofilm Formation}

Biofilm biogenesis is a dynamic process that involves a consecutive series of steps $[46,47]$. The process of biofilm formation commences by the bacteria approaching to a surface. Most bacteria have the ability to switch between two forms that are planktonic single cells and sessile biofilms. The planktonic cells and biofilms vary remarkably in their gene expression, morphological and physiological facets. The sessile cells are encapsulated by extracellular polysaccharides (EPS) and demonstrate increased production of surface adherents, innate tolerance to antibiotics, and soaring resistance towards environmental stress.

The biofilm formation process (Figure 1) involves different phases:

\subsection{Reversible Attachment}

Under favorable conditions, a single planktonic cell migrates and reversibly attaches itself onto a surface initiating the first phase of the biofilm biogenesis process [48,49]. Being reversible, this attachment involves weak interactions such as electrostatic, van der Waals or hydrophobic interactions. Cell appendages such as pilli, flagella or fimbriae provide robustness and adhesion to the surface of attachment. On attachment the cells become further become encapsulated in EPS [50,51].

\subsection{Microcolony Formation with Quasi-Irreversible Adhesion}

In this stage the planktonic cells become prominently more layered and form a systematic microcolony along with water channels making it an irreversible adhesion. Colonization, a hallmark feature of biofilms, plays a vital role in its dormancy and virulence. Once the cells securely adhere to an appropriate surface countless microbes pile up and 
secrete EPS that acts as a sealant to fix the microorganisms. After these synchronized steps the microcolonies are formed [52-54].

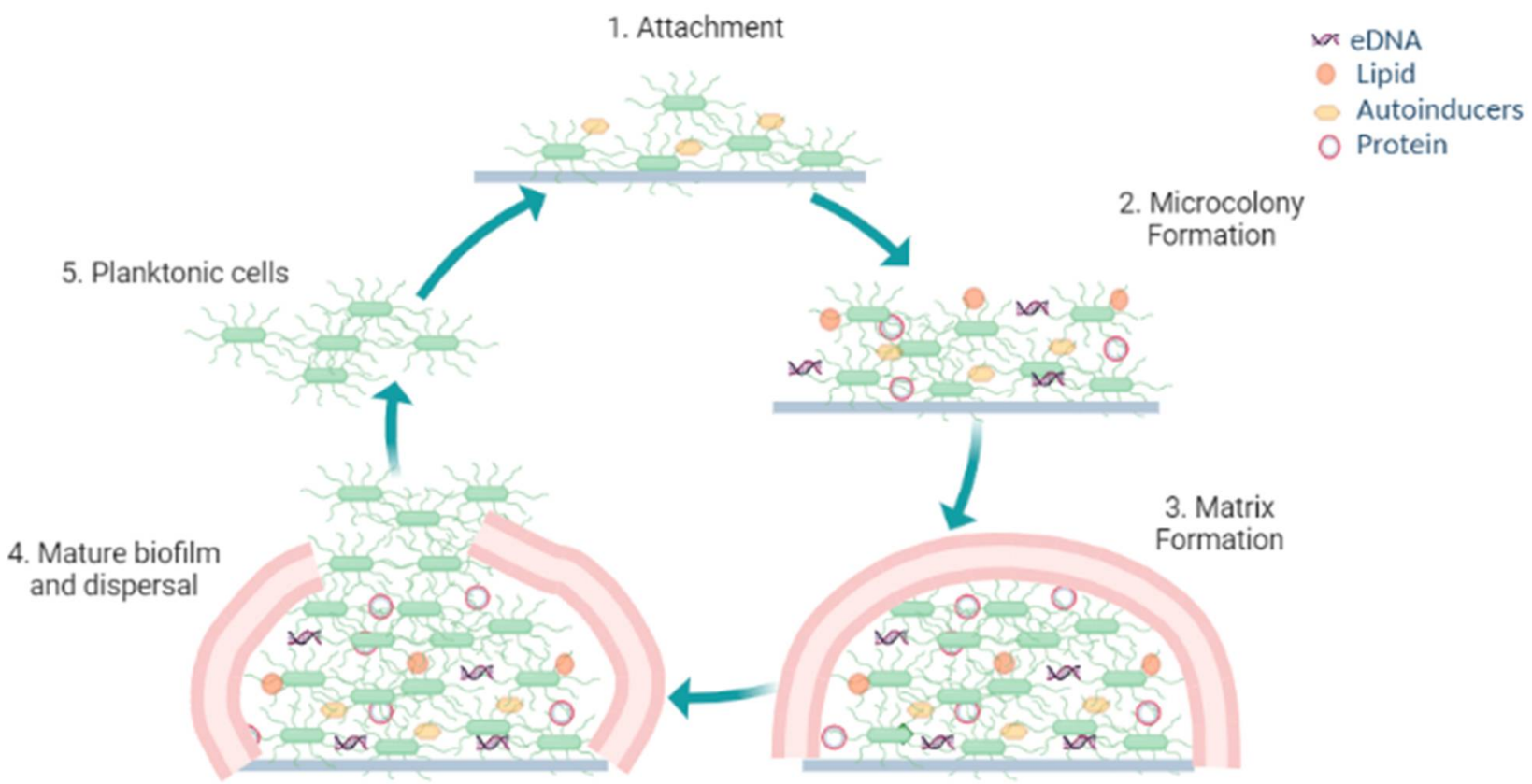

Figure 1. Biofilm formation process.

\subsection{Biofilm Matrix Formation}

The EPS produced by the adherent forms a matrix within which the cells build their community and attain their maximum cell density. The EPS encapsulating the cells in a biofilm is an amalgamation of constituents, including extracellular-DNA (e-DNA), autosensing molecules, persister cells, proteins, lipids and polysaccharides [55-58]. The polysaccharides in the matrix provide strength to the cells within the biofilm, such as adherence, shielding, and structural rigidity $[59,60]$. Colonization is facilitated by the aggregative polysaccharides that act as glue and also provide protection from physical stresses inflicted by the moving fluid depriving the cells of nutrients [61-63]. Organisms inherit different kinds of polysaccharides that exhibit key roles in biofilm integrity (Table 1). The nucleic acids like e-DNA, extracellular-RNA (e-RNA) and ribosomal DNA interact with different EPS granting nutrients, providing structural stratification and protection against any gene transfer to the biofilm. The proteins present in the matrix bestow structure and stability to the biofilm [64-66]. The persister cells contribute to a small community of dormant cells that display utmost resistance towards antimicrobials [67-70].

\subsection{Maturation of the Biofilm and Detachment}

With availability of favorable conditions and nutrients the cells grow and differentiate to form mature biofilms which have a spatial architecture. This well developed biofilm resembles a communal group arbitrated by chemical signaling molecules liberated by bacterial inhabitants within the biofilm. On maturation, the microcolonies of cells release individual planktonic cells now capable of travelling to a new surface, thus leading to outspread of the bacterial infestation [98-101]. 
Table 1. Bacterial polysaccharides formed by different organisms and their functions.

\begin{tabular}{|c|c|c|c|}
\hline Bacterial Polysaccharide & Organisms & Function & References \\
\hline $\begin{array}{l}\text { Polysaccharide intercellular } \\
\text { adhesion (PIA) }\end{array}$ & $\begin{array}{l}\text { Staphylococcus aureus, } \\
\text { Staphylococcus epidermidis }\end{array}$ & $\begin{array}{c}\text { Adhesion and } \\
\text { architectural framework }\end{array}$ & [71-73] \\
\hline Pel & Pseudomonas aeruginosa & $\begin{array}{l}\text { Adhesion, protection and } \\
\text { architectural framework }\end{array}$ & {$[74,75]$} \\
\hline Psl & Pseudomonas aeruginosa & $\begin{array}{l}\text { Adhesion, protection and } \\
\text { architectural framework }\end{array}$ & {$[76,77]$} \\
\hline Alginate & $\begin{array}{l}\text { Pseudomonas aeruginosa, } \\
\text { Pseudomonas syringae }\end{array}$ & $\begin{array}{c}\text { Protection and } \\
\text { architectural framework }\end{array}$ & {$[78,79]$} \\
\hline Capsular polysaccharides (CPSs) & $\begin{array}{c}\text { Pasteurella multocida, } \\
\text { Acinetobacter baumannii, } \\
\text { Streptococcus pneumoniae, } \\
\text { Vibrio vulnificus }\end{array}$ & Protection & [80-84] \\
\hline Levan & $\begin{array}{c}\text { Pseudomonas syringae, Erwinia } \\
\text { amylovora, Bacillus subtilis, } \\
\text { Streptococcus mutans }\end{array}$ & Adhesion and protection & {$[85,86]$} \\
\hline Colanic Acid & Enterobacteriaceae & Architectural framework & {$[87,88]$} \\
\hline Vibrio & Vibrio cholerae & $\begin{array}{c}\text { Adhesion, } \\
\text { architectural framework }\end{array}$ & [89-92] \\
\hline$\alpha$-Mannans and $\beta$-glucans & Candida albicans & $\begin{array}{l}\text { Forming mannan-glucan complex } \\
(\mathrm{MGC}) \text { and protection }\end{array}$ & {$[93,94]$} \\
\hline Glucans/fructans & $\begin{array}{l}\text { Streptococcus mutans, Weissella } \\
\text { cibaria, Lactobacillus plantarum }\end{array}$ & Adhesion and protection & [95-97] \\
\hline
\end{tabular}

\section{Mode of Action of Antibiofilm Agents}

\subsection{Bacterial Surface Attachment Inhibition}

Bacterial appendages like flagella or fimbriae aid their attachment to surfaces, so inhibition of these appendages can be an approach to avert adhesion. Surface coating or surface modification with agents having antibacterial properties is an emerging technique to hostile microbial adhesion and proliferation [102-106]. Inhibition of bacterial adhesion can be achieved by surface coating with biocidal agents or specific polymers having an ability to inhibit the cells impending the surface. Indeed, novel polysaccharides from Antarctic sponge-associated bacteria and lake macroalgae have recently been used to hinder the adhesion of bacteria $[107,108]$. Surface topography using nanotechnology has recently been explored to generate antibacterial surfaces [109-112].

\subsection{Interfering with Quorum-Sensing}

Microbial cell-to-cell communication at the molecular level, which enables the microbes to reciprocate to surrounding changes, is permitted by a mechanism called quorumsensing (QS). QS is reliant on the binding of an autoinducer to an analogous gene regulator, which activates the ensuing transcriptions [113-117]. Examples of autoinducers are Nacyl homo-serine lactones (AHLs) (1) and Pseudomonas quinoline signaling molecules (2) present in Gram-negative species, short peptide signals present in Gram-positive species, and autoinducer-2 (3) molecules found in both species (Figure 2). These help to control population density, swarming motility, virulence and biofilm formation [118-120]. The autoinducers initiate the formation of virulence factors that aid invasion and persistence in a vulnerable host. QS systems are associated with upregulation of gene expression through the accessory gene regulator $(a g r)$ system, forming virulence factors such as adhesins, toxins, hemolysin and autolysins in Gram-positive staphylococcal infections or siderophores, exoproteases, rhamnolipids and exotoxins in P. aeruginosa [121-124]. The formation of biofilms and related virulence factors by infective microbes requires cell-cell 
communication, hence agents acting as QS inhibitors and specifically targeting the AHL-QS system in bacteria have been widely explored for their efficacy using in vitro and in vivo models [125-127].<smiles>[R]C(=O)NC1CCOC1=O</smiles>

N-Acyl homoserine lactones 1<smiles>CCn1cc(O)c(=O)c2ccccc21</smiles>

\section{Pseudomonas quinoline signaling 2}

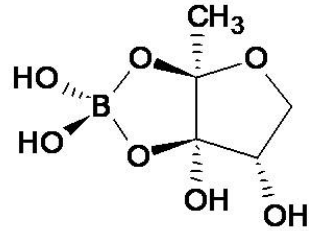

Autoinducer-2 3

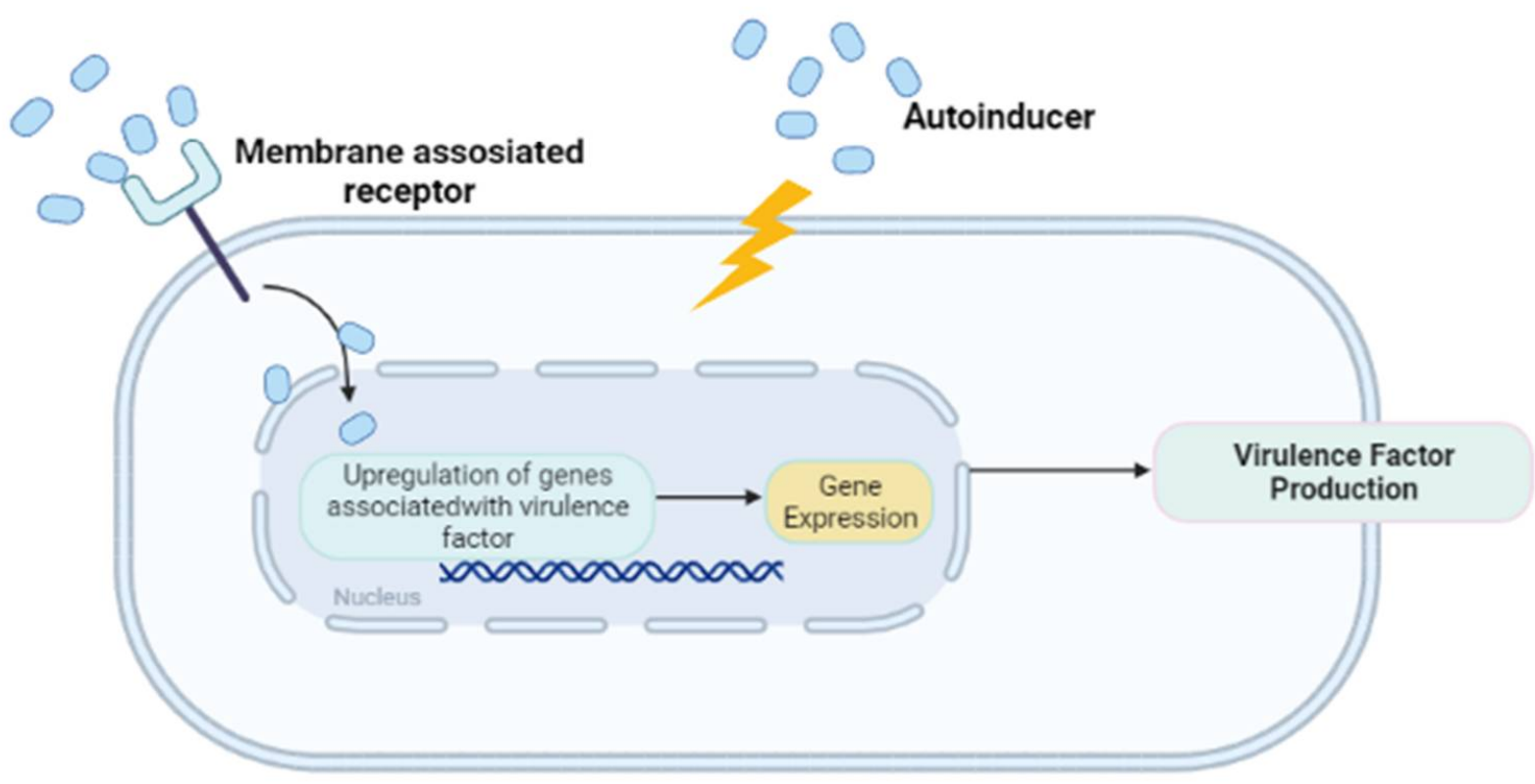

Figure 2. Chemical structures of some autoinducers (top) and production of virulence factors (bottom).

\subsection{Nucleotide Second Messenger Signaling Modulating Molecules}

The second messenger cyclic di-guanosine monophosphate (c-di-GMP) has emerged as a signaling molecule in Gram-positive and Gram-negative bacteria governing the process of biofilm formation, biosynthesis of EPS, virulence and suppression of cell motility. The enzyme diguanylate cyclase is essential for synthesis of c-di-GMP, inhibition of which has proven to terminate biofilm formation, alluding to the significance of c-di-GMP in the bacterial signaling process [128-135].

\subsection{Bacterial Genetic Biodiversification Inhibitors}

Genetic biodiversification in bacteria leads to emergence of newer subpopulations, which have been ascribed to be resistant to antibiotic therapies and environmental stressors. Horizontal gene transfer with conjugation plays a crucial role in the outspread of resistance in biofilm colonies [136-138]. The social evolution theory anticipates that inhibiting shared traits among the subpopulations could be a viable solution for eradicating the biofilm. The fact that the organism in a subpopulation relies on a shared EPS makes it an interesting target to combat genetic diversification. The spatial structure and heterogeneity provided by biofilms lead to increased genetic diversity [139]. 


\subsection{Biofilm Dispersal Inducers}

Biofilm dispersal is initiated by the disruption of the EPS matrix to release the microcolonies of planktonic cells that migrate and adhere to new surfaces. Antibiofilm agents that can abet the process of dismantling the biofilm has provided research strategies for designing new biofilm dispersal inducers [140-142]. This dispersal process provides an opportunity to target the microorganisms since they now exist in their viable form, a way more susceptible form permitting the attack of standard antimicrobials comparable to cells residing in the biofilm $[143,144]$. Biofilm dispersal agents have triggered the interest of researchers to design combination treatments along with antibiotics.

\section{Bacterial Resistance towards Antibiotics}

When antibiotics are intended to treat biofilm infestation, they must have the ability to cross the biofilm matrixome to target the cells embedded within. Although this is not the case most of the time as the antibiotics fail to cross the biofilm extracellular matrix due to surface modification of the biofilm causing decreased influx. The mechanisms by which antibiotic resistance develops are a crucial determinant factor in the survival of biofilm microbes. The microbes that form biofilms inherently undergo high mutation that allows them to evolve resistant mechanisms providing fortuity for genes to develop enzymes that inactivates the antibiotics or extrudes the antibiotics by efflux pumps [145-148].

Four major mechanisms are involved in the antibiotic resistance developed among bacterial species (Figure 3):

i. Modifying cell permeability to restrict the influx of antibiotics into the cells.

ii. Altering the cellular targets to which the antibiotics bind, rendering them inactive.

iii. Enzymatic cleavage of the antibiotics making them ineffective.

iv. Upregulation of efflux pumps to expel the antibiotics out of the cellular membrane.

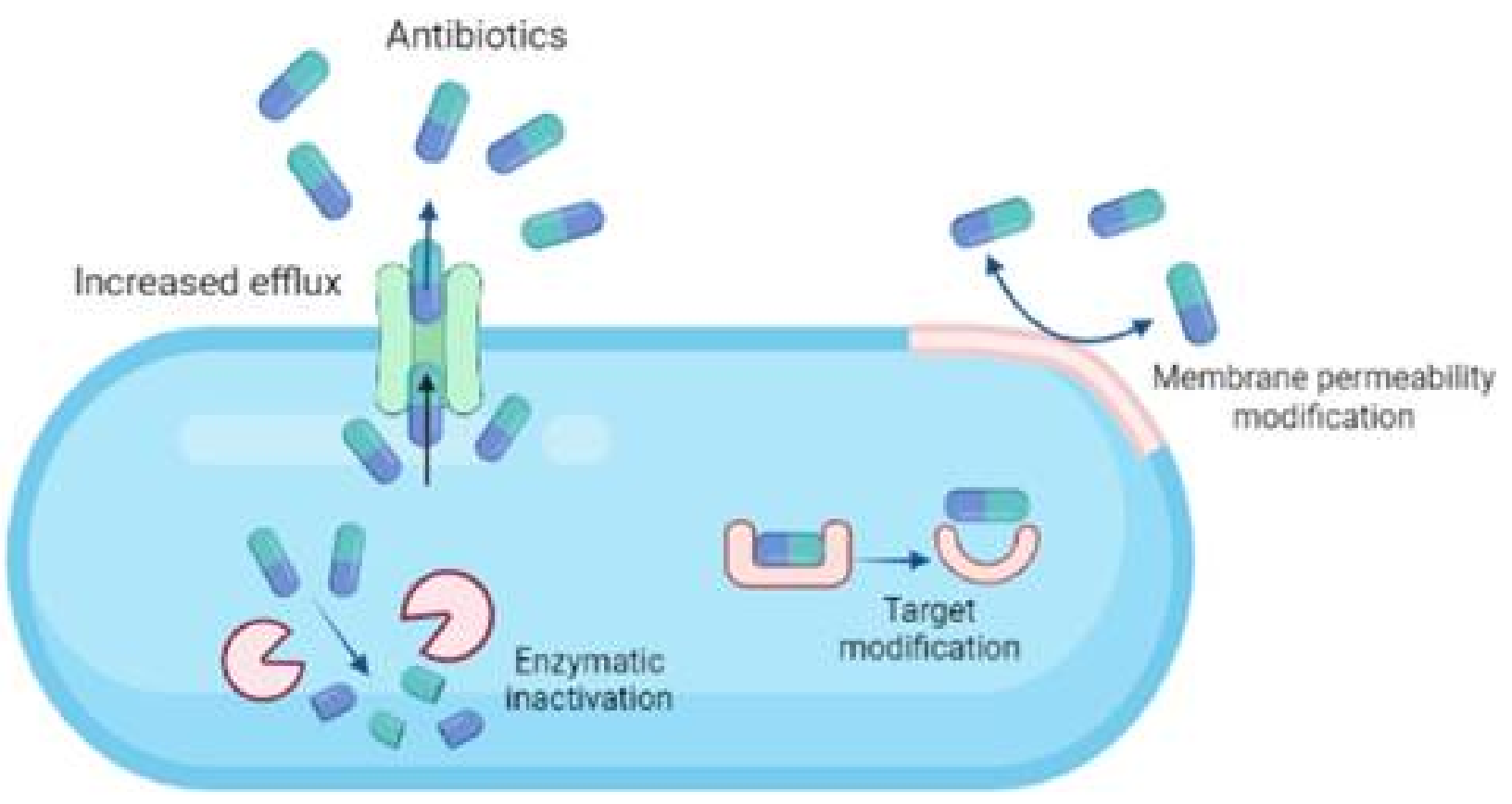

Figure 3. Major mechanisms involved in the development of antibiotic resistance among bacterial species.

Horizontal gene transfer in plasmids and the portability of human carriers has resulted in proclamation of drug resistance over a capacious microbial subdivision and microenvironment [149-153]. 


\section{Emerging Antibiofilm Agents}

Biofilms embrace the capability to resist and survive harsh environmental conditions and defeat the host immune system, so there is a desire for exploring new antibiofilm agents. Emerging biofilm control measures such as small molecule inhibitors, quorum quenching agents, antimicrobial peptides (AMPs), efflux pump inhibitors (EPIs), quaternary ammonium compounds (QACs), and natural phytoconstituents are gaining acclaim to selectively act by different mechanisms and combat the resistance. With the unfolding knowledge of biofilm biogenesis and microenvironments, various agents and newer emerging technologies have provided novel approaches for selectively targeting the biofilm by annihilating the biofilm or suppressing its formation.

\subsection{Inhibition of Persister Cell Formation by a Synthetic Diterpene}

Tkachenko et al. identified a synthetic diterpene derivative as a lead molecule proficient in repressing resistance and annihilating the biofilm formation in Mycobacterium smegmatis. Persister cell formation in Mycobacterium is highly dependent on the alarmone (p)ppGpp and its essential Rel protein. The analogue 4-(4,7-di-methyl-1,2,3,4-tetrahydro-naphthalene-1yl)pentanoic acid (DMNP) (4) (Figure 4) was found to inhibit RelMsm activity of (p)ppGppsynthesis in a concentration-dependent manner [154]. Furthermore, docking studies suggested the interaction of DMNP with RelZ and RelMsm proteins and high affinity with their GTP binding sites, consequently impeding their (p)ppGpp-synthesizing activity [155].

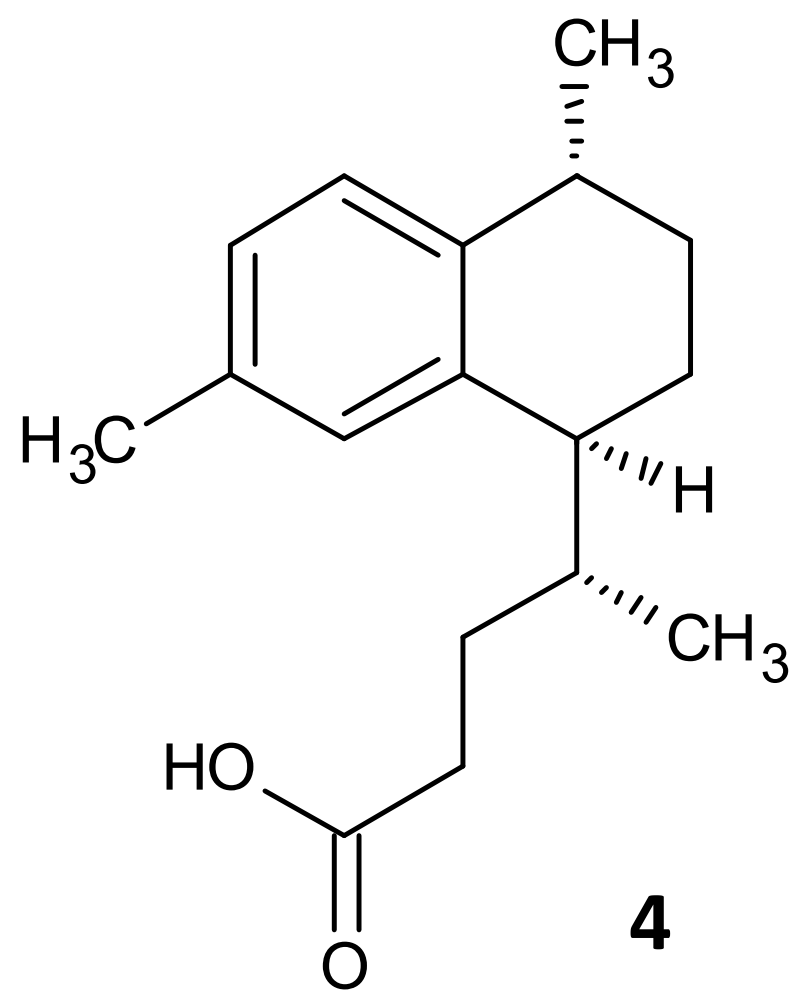

Figure 4. Chemical structure of DMNP.

\subsection{Inhibition of Sortase A by 1,2,4-Oxadiazole Topsentin Analogs}

A series of seventeen 1,2,4-oxadiazole topsentin analogs was synthesized by Parrino et al. and assessed for their biofilm inhibition, by targeting the membrane enzyme transpeptidase sortase A (SrtA), which attaches surface adhesive molecules to the cell wall in Gram-positive organisms. All these compounds inhibited biofilm formation in S. aureus species with BIC50 values less than $10 \mu \mathrm{M}$ for the most potent derivatives (5a-c). The potent analogues displayed BIC50 values for S. aureus in the range of 0.7 to $9.7 \mu \mathrm{M}$, and additionally showed a superior enzyme inhibition with IC50 values of 2.2 to $10.4 \mu \mathrm{M}$. SAR 
analysis revealed the significance of the presence of the $-\mathrm{N}=\mathrm{C}-\mathrm{O}$ - group in the oxadiazoles for dual antibacterial and biofilm inhibitory activity [156]. In a similar work by Carbone et al., thiazole analogs of nortopsentin were synthesized of which the potent derivatives $\mathbf{6 a}-\mathbf{b}$ showed BIC50 values against $S$. aureus of 3.9 and $1.0 \mu \mathrm{M}$ (Figure 5 and Table 2) [157].<smiles>[R]c1ccc2c(c1)c(C(=O)c1nc(-c3cn(C)c4ccc([R])cc34)no1)cn2C</smiles>

$5 a-c$<smiles>COCCn1cc(-c2nc(-c3ccsc3)cs2)c2cc(F)ccc21</smiles>

$6 a$<smiles>COCCn1cc(-c2nc(-c3cccnc3)cs2)c2cc(Br)ccc21</smiles>

$6 b$

Figure 5. Chemical structures of potent 1,2,4-oxadiazole topsentin analogs.

Table 2. BIC50 values for 1,2,4-oxadiazole topsentin analogues.

\begin{tabular}{|c|c|c|c|}
\hline Compound & $\mathbf{R}$ & $\mathbf{R}^{\prime}$ & $\begin{array}{l}\text { BIC50 Values for } \\
\text { S. aureus ( } \mu \mathrm{M})\end{array}$ \\
\hline $\begin{array}{l}\text { (5-floro-1-methyl-1H-indol-3-yl)[3-(5-bromo-1-methyl-1H- } \\
\text { indol-3-yl)-1,2,4-oxadiazol-5-yl]methanone (5a) }\end{array}$ & $\mathrm{F}$ & $\mathrm{Br}$ & 4.4 \\
\hline $\begin{array}{l}\text { (5-floro-1-methyl-1H-indol-3-yl)[3-(5-floro-1-methyl-1H-indol- } \\
\text { 3-yl)-1,2,4-oxadiazol-5-yl]methanone }(\mathbf{5 b})\end{array}$ & $\mathrm{F}$ & $\mathrm{F}$ & 0.27 \\
\hline $\begin{array}{l}\text { (5-methoxy-1-methyl-1H-indol-3-yl)[3-(5-methoxy-1-methyl- } \\
\text { 1H-indol-3-yl)-1,2,4-oxadiazol-5-yl]methanone (5c) }\end{array}$ & $\mathrm{OCH}_{3}$ & $\mathrm{OCH}_{3}$ & 0.9 \\
\hline $\begin{array}{l}\text { 5-fluoro-1-(2-methoxyethyl)-3-[4-(thiophen-3-yl)-1,3-thiazol-2- } \\
\text { yl]-1H-indole (6a) }\end{array}$ & - & - & 3.9 \\
\hline $\begin{array}{l}\text { 5-bromo-1-(2-methoxyethyl)-3-[4-(pyridin-3-yl)-1,3-thiazol-2- } \\
\text { yl]-1H-indole (6b) }\end{array}$ & - & - & 1.0 \\
\hline
\end{tabular}

\subsection{Amide Chalcones}

El-Messerya et al. synthesised a panel of amide chalcones linked with different secondary amines and assessed them for in vitro antibacterial activity and their antibiofilm activity. A minimum bactericidal concentration (MBC) value of $2.0 \mathrm{mg} / \mathrm{mL}$ against $S$. aureus equivalent to the standard ampicillin was shown by compound $\mathbf{7 a}$. Compounds $\mathbf{7 a}, \mathbf{7 b}$, and 7c (Figure 6) displayed a significant biofilm inhibition with IC50 values in the range of 2.4 to $8.6 \mathrm{mg} / \mathrm{mL}$ against S. aureus, Micrococcus luteus and P. aeuroginosa (Table 3) [158,159].<smiles>[R]c1ccc(/C=C/C(=O)c2ccc(NC(=O)CCN3CCCCC3)cc2)cc1</smiles>

Figure 6. Chemical structure of amide chalcones. 
Table 3. IC50 values for amide chalcones.

\begin{tabular}{|c|c|c|c|c|}
\hline \multirow{2}{*}{ Compound } & \multirow{2}{*}{$\mathbf{R}$} & \multicolumn{3}{|c|}{ Bacterial Biofilm Inhibition (IC50 in $\mu \mathrm{M} \pm \mathrm{SD}$ ) } \\
\hline & & S. aureus & M. luteus & P. aeuroginosa \\
\hline $\begin{array}{l}\text { (E)-N-(4-(3-(4-Chlorophenyl)acryloyl)phenyl)-3- } \\
\text { (piperidin-1-yl)propanamide (7a) }\end{array}$ & $4-\mathrm{Cl}$ & $2.4 \pm 0.10$ & $4.8 \pm 0.11$ & $7.8 \pm 0.24$ \\
\hline $\begin{array}{l}\text { (E)-N-(4-(3-(4-Methoxyphenyl)acryloyl)phenyl)- } \\
\text { 3-(piperidin-1-yl)propanamide (7b) }\end{array}$ & $4-\mathrm{OCH}_{3}$ & $4.9 \pm 0.21$ & $5.7 \pm 0.26$ & $8.6 \pm 0.22$ \\
\hline $\begin{array}{l}\text { (E)-3-(Piperidin-1-yl)-N-(4-(3-(3,4,5- } \\
\text { trimethoxyphenyl)acryloyl)phenyl)propanamide (7c) }\end{array}$ & $3,4-\operatorname{di}\left(\mathrm{OCH}_{3}\right)$ & $2.9 \pm 0.16$ & $5.6 \pm 0.22$ & $0.84 \pm 0.21$ \\
\hline
\end{tabular}

\subsection{Cajaninstilbene Acid Derivatives}

Chen and co-workers recently developed cajaninstilbene acid derivatives and evaluated their ability to inhibit biofilm formation. Of the synthesized analogues, compounds $\mathbf{8 a}, \mathbf{8 b}$ and $\mathbf{8 c}$ (Figure 7) exhibited promising antibiofilm activity, furthermore $\mathbf{8 c}$ displayed potent biofilm inhibition with a ratio of $49.50 \pm 1.35 \%$ at $50 \mu \mathrm{M}$ (Table 4). Additionally, compound 8c showed suppression on expression of lasB-lacZ and pqsA-lacZ involved in the QS network pathway in P. aeruginosa. Thereby proving compound $8 \mathbf{c}$ as a promising lead with inhibition of QS and associated biofilm formation in P. aeruginosa [160,161].<smiles>[R]C=Cc1cc(OC)c(CC=C(C)C)c(O)c1C(=O)O</smiles>

\section{$8 a-c$}

Figure 7. Chemical structure of cajaninstilbene acid derivatives.

Table 4. Biofilm inhibition ratios for cajaninstilbene acid derivatives.

\begin{tabular}{|c|c|c|}
\hline Compound & $\mathbf{R}$ & Biofilm Inhibition Ratio (\%) \\
\hline $\begin{array}{l}\text { 2-hydroxy-4-methoxy-3-(3-methylbut-2-en-1-yl)-6-[(Z)-2- } \\
\text { (pyrimidin-5-yl)ethenyl]benzoic acid (8a) }\end{array}$ & & $36.11 \pm 0.58$ \\
\hline $\begin{array}{l}\text { 2-hydroxy-4-methoxy-3-(3-methylbut-2-en-1-yl)-6-[(Z)-2- } \\
\text { (quinolen-8-yl)ethenyl]benzoic acid (8b) }\end{array}$ & & $35.61 \pm 3.76$ \\
\hline $\begin{array}{l}\text { 2-hydroxy-4-methoxy-3-(3-methylbut-2-en-1-yl)-6-[(Z)-2- } \\
\text { (sulfurpentafloro-benzene-4-yl)ethenyl]benzoic acid (8c) }\end{array}$ & & $49.50 \pm 1.35$ \\
\hline
\end{tabular}

\subsection{Quorum Quenching Agents}

The persister cells have the ability to communicate amongst themselves leading to virulence and the generation of resistance. Different quorum quenching agents have been 
explored in order to find adjuvant therapy. The bacterial QS inhibitory effect of subtilosin (9), a cyclic lantibiotic formed by B. subtilis KATMIRA1933, was assessed by Algburi et al. [162]. Subtilosin shows its effect by targeting the surface receptor and binding to the bacterial cell membrane by electrostatic forces. The study revealed that at a concentration of $15.1 \mu \mathrm{g} / \mathrm{mL}$ an inhibition of $80 \%$ of L. monocytogenes and about $60 \%$ of E. coli biofilms was seen. Moreover, subtilosin decreased the autoinducer-2 formation in Gardnerella vaginalis at a concentration of 3-4 $\mu \mathrm{g} / \mathrm{mL}$ [152]. Zhou et al. evaluated the QS inhibitory potential of hordenine (10) isolated from sprouting barley towards P. aeruginosa. It was found to inhibit the autoinducer AHLs at concentrations of 0.5 to $1.0 \mathrm{mg} / \mathrm{mL}$. Additionally, it also remarkably suppressed the QS associated genes lasR, rhlR, rhlI and lasI [163]. In another work by Zhao et al. the QS inhibitory effect of falcarindiol (11) against P. aeruginosa infestation was assessed. Biofilm formation and associated virulance factors were significantly inhibited at subinhibitory concentrations. Also, there was appreciable downregulation of the mRNA expression of QS associated genes lasI, lasB, rhlA, pqsA, rhlR, phzH and $r h l$ I [164]. QS and biofilm inhibitory effects of a few hordenine derivatives towards $P$. aeruginosa and Serratia marcescens was recently analysed by Liu et al. Derivatives 12a-g exhibited superior QS inhibitory activity and biofilm inhibition towards $P$. aeruginosa. Additionally, analogues 12a-c and $\mathbf{1 2} \mathrm{g}$ displayed remarkable QS inhibition against $S$. marcescens. SAR studies revealed essential factors involved in activity like alkyl chain length, presence or absence of amino or hydroxyl groups and unsaturation in the aromatic benzene ring [165]. A thiolactone analog of AHL covalently linked to ciprofloxacin (QS0108) (13) was developed by Ganguly et al. to assess them as inhibitors of AHL-2 in P. aeruginosa. This system effectively disrupted dormant and mature biofilms compared to antibiotic treatment alone (Figure 8) [166].

\subsection{Antimicrobial Peptides}

AMPs are emerging as attractive antibiofilm agents owing to various properties that they display, such as a broad-spectrum of antimicrobial activity, decreased resistance and synergistic effects shown with few antibiotics. Indeed, these properties mean that AMPs could become the next generation of antimicrobials to curb the biofilm related resistance shown by current antibiotics.

Heinonen et al. recently explored the antibiofilm effect of TAT-RasGAP317-326, an AMP made of a TAT HIV 48-57 sequence which gives it cell permeability, and a sequence of ten amino acids obtained from the Src homology domain of p120 RasGAP on biofilms of $P$. aeruginosa, A. baumannii and S. aureus. It was observed that TAT-RasGAP317-326 attenuated biofilm formation at concentrations similar to or twice the MIC value obtained for planktonic cells. Additionally, TAT-RasGAP317-326 curbed the growth and spread of P. aeruginosa and A. baumannii preformed biofilms at twice the concentration. This study proclaims TAT-RasGAP317-326 as a propitious antibiofilm AMP [167].

Wuersching et al. assessed the effect of AMPs LL-37 (also known as cathelicidin) and human lactoferricin (LfcinH) on the growth of planktonic cells and biofilm formation in anaerobes associated with oral pathogenesis. Suspensions of multi-species of facultative anaerobic bacteria (FAB) including Actinomyces naeslundii, Streptococcus mutans and Streptococcus sanguinis or obligate anaerobic bacteria (OAB) including Parvimonas micra, Veillonella parvula and Fusobacterium nucleatum were subjected to concentration ranges of LL-37 and LfcinH. Compared to LfcinH, prominent inhibitory threshold concentrations of LL-37 were noticed $(p<0.0001)$ but the biofilm mass was also decreased better by LL-37 compared to LfcinH, highlighting the scope of LL-37 as a better AMP $[168,169]$.

Ciandrini et al. investigated the synergistic action of AMPs citropin 1.1, temporin A, Pal-KGK- $\mathrm{NH}_{2}$ and $\mathrm{CA}(1-7) \mathrm{M}(2-9) \mathrm{NH}_{2}$ towards methicillin-resistant S.s aureus (MRSA) biofilms formed on a polystyrene surface and a central venous catheter. The combination evidently inhibited biofilm formation, although, disruption of preformed biofilms was tedious and achieved after $24 \mathrm{~h}$ of contact $[170,171]$. 
Festa et al. recently worked on the AMP 1018-K6 as an antibiofilm agent against MRSA and enterotoxigenic $S$. aureus isolated from cheese. This peptide exhibited remarkable eradication of preformed Staphylococcal biofilms within $15 \mathrm{~min}$. Moreover, it prevented further formation of biofilms and displayed bactericidal action against the planktonic cells [172]. In a continuation of the work on 1018-K6, Colagiorgi et al. worked on the antibiofilm ability of the food pathogen Salmonella enterica. Of the 42 strains included in the study, 1018-K6 profoundly decreased the biofilm formation in several S. enterica strains at subinhibitory concentrations [173].

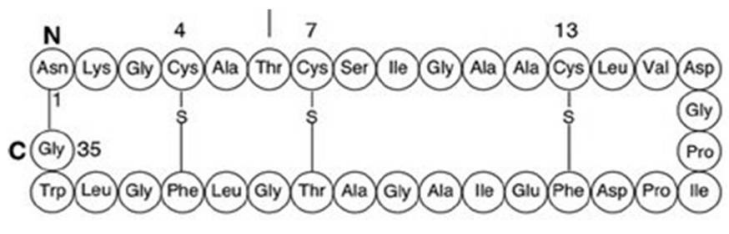

Subtilosin 9<smiles>NCCCc1ccccc1</smiles>

3-Phenylpropan1-amine 12a<smiles>NCCc1ccc(O)cc1</smiles>

4-(2-Aminoethyl)phenol 12d<smiles>CNC/C=C/c1ccccc1</smiles>

(2E)-N-Methyl-3-phenylpropen-1-amine 12g

\section{Hordenine 10}<smiles>Oc1ccccc1</smiles><smiles>NC/C=C/c1ccccc1</smiles>

(2E)-3-phenylprop-2-en1-amine 12b<smiles>CNCCc1ccccc1</smiles>

N-Methyl-2-phenylethane1-amine 12e

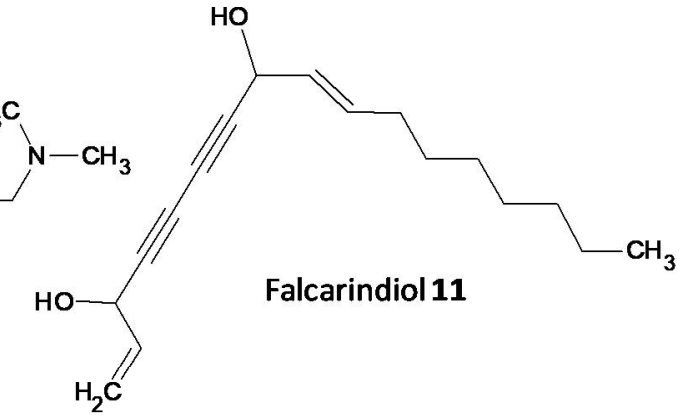<smiles>CNCCCc1ccccc1</smiles>

N-Methyl-3-phenylpropane1-amine 12c<smiles>NCCc1ccccc1</smiles>

2-Phenylethan-1-amine $12 f$

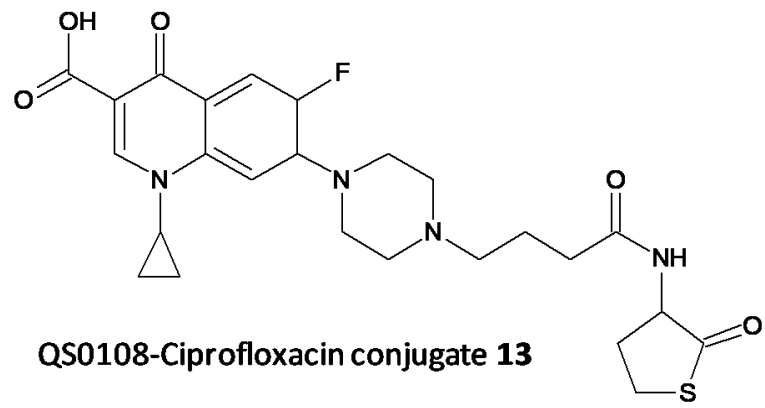

Figure 8. Chemical structures of various quorum sensing inhibitors.

\subsection{Antibiotics Affecting Bacterial Cell Permeability}

Antibiotics affecting cell permeability target several components of the cell wall and its synthesis. The peptidoglycan class of antibiotic vancomycin inhibits the cell wall synthesis by complex formation with the D-Ala-D-Ala subunit at the carboxyl terminal in a peptidoglycan chain [174-176]. AMPs like polymyxin B pile up in the outer membrane by binding to lipid A and eventually invade the inner membrane making its way into the cytoplasm. The resistance to this antibiotic is seen by either mutations in the governing 
<smiles>NC(=O)[C@@H]1CC[C@@H]2CN1C(O)N2OS(=O)(=O)[O-]</smiles>

Avibactam 14

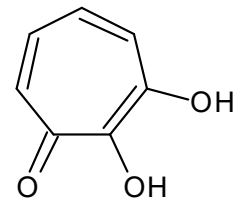

7-Hydroxytropolone 15 systems PmrAB and PhoP/PhoQ or modification of the phosphate functional groups of lipid A [177,178].

\subsection{Enzymatic Cleavage Inhibitors}

On being exposed to an antibiotic the bacterial cells inturn release enzymes which act in a defensive way in the extracellular space, cleaving and deactivating the antibiotic. The resistance to beta-lactam antibiotics has been associated to the enzyme beta-lactamase. A combination of ceftazidime and a beta-lactamase inhibitor avibactam has been explored for its antibiofilm activity towards carbapenemase-producing K. pneumoniae. Avibactum (14) was also proven to irreversibly curb the $\beta$-lactamase enzyme from Mycobacterium tuberculosis [179-182]. 7-Hydroxytropolone (15) acts as an inhibitor of the enzyme aminoglycoside-2"-Oadenylyltransferase and was active against bacterial strains resistant to amioglycosides. The structure of 7-hydroxytropolone, exhibits an eccentric vicinal positioning of the oxygens which aids in the enzyme inhibition [183]. Plazomicin (ACHN-490) (16) a neamine derivative was designed by modifying the sites that displayed affinity to the resistance caused by aminoglycoside-modifying enzymes allowing it to preserve the antimicrobial activity towards pathogens that possess aminoglycoside resistance genes [184,185] (Figure 9).

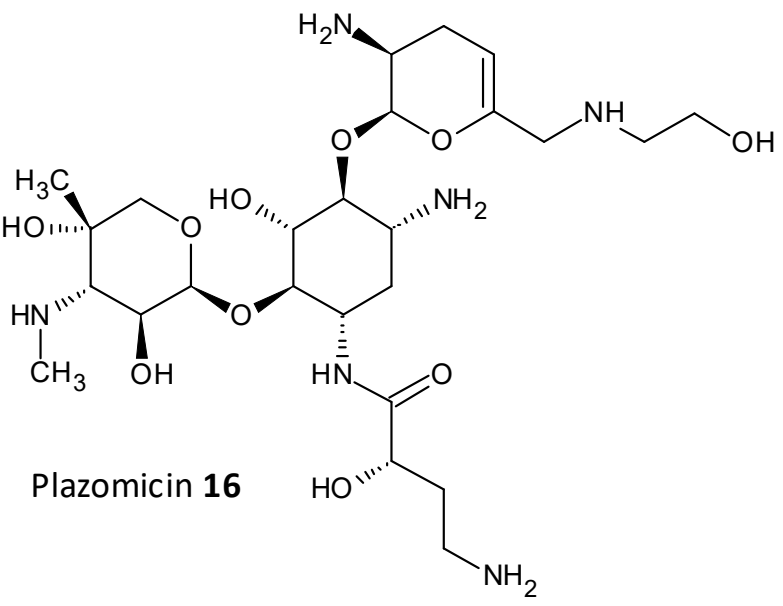

Figure 9. Chemical structures of some enzymatic cleavage inhibitors.

\subsection{Efflux Pump Inhibitors}

Efflux of antibiotics, by overexpression of efflux pumps, leads to their extrusion out of the cell, making them inactive. EPIs are a recent class of compounds which specifically aim to prevent the efflux of antibiotics out of the cell, which is a determinant of the resistance shown toward antibiotics. A peptidomimetic efflux pump inhibitor MC-207,110 (17a), also known as phenylalanyl arginyl $\beta$-naphthylamide, and its analogue MC-04124 (17b) (Figure 10) enhanced the antimicrobial activity of erythromycin and levofloxacin against clinical strains of P. aeruginosa overexpressing MexAB-OprM [186,187]. A synthetic small molecule IITR08027 (18) (Figure 10) showed reversal of resistance towards fluoroquinolones in clinical strains of $A$. baumannii overexpressing multidrug and toxic compound extrusion (MATE) efflux pumps and the recombinant strains of E. coli. IITR08027 disrupts the proton gradient important for activating the efflux pump [188]. MBX2319 (19) a pyrazolopyridine analogue displayed inhibition of AcrAB-TolC-overexpressing in E. coli and potentiated the efficacy of antibiotics like levofloxacin, ciprofloxacin, and piperacillin [189] (Figure 10).

\subsection{Quaternary Ammonium Compounds}

QACs represent a class of broad-spectrum antimicrobials possessing a central amphiphilic core and a lipophilic alkyl side chain linked to a hydrophilic quaternary ammonium framework. Although QACs imitate the action of the AMPs they have a comparatively simplified structure. The mode of action of these agents as antimicrobials is by cleavage 
of the cell membrane, which consequently leads to nutrient leakage followed by cell lysis and death. Although, this class of compounds have already been established as disinfectants, antiseptics and preservatives their role as antibiofilm agents has only recently been recognised.<smiles>NC(N)=NCCC[C@H](NC(=O)[C@H](N)Cc1ccccc1)C(=O)Nc1ccc2ccccc2c1</smiles>

MC-207,110 17a<smiles>CSc1ccc(/N=C2\NC(=O)C(CC(=O)Nc3ccc(F)c(F)c3)S2)cc1</smiles>

IITR08027 18<smiles>NC[C@@H]1CNC(C(=O)N[C@@H](CCc2ccccc2)C(=O)Nc2ccc3ncccc3c2)C1</smiles>

MC-04124 17b<smiles>CC1(C)Cc2c(C#N)c(SCCc3ccccc3)nc(N3CCOCC3)c2CO1</smiles>

MBX2319 19

Figure 10. Chemical structures of some efflux pumps inhibitors.

In a study by Kumar Tiwari et al. two quaternary ammonium methacrylate (QAM) derivatives, dimethylaminododecyl methacrylate (DMADDM) (20) and dimethylaminohexadecyl methacrylate (DMAHDM) (21), were designed and evaluated for their efficacy as antibiofilm agents against E. faecalis, Streptococcus gordonii, Actinomyces naeslundii, and Lactobacillus acidophilus using chlorhexidine and sodium hypochlorite as standards. In particular, the minimal biofilm inhibitory concentration (MBIC) for DMADDM and DMAHDM against a combination of four endodontic bacteria was $25 \mu \mathrm{g} / \mathrm{mL}$ and $6.25 \mu \mathrm{g} / \mathrm{mL}$, respectively [190]. Daood et al. investigated quaternary ammonium silanes (QASs) (22) as biofilm disruptors by exposing them to $S$. mutans and L. acidophilus preformed biofilms over dentine disks, at different concentrations. Inhibition of enzyme SrtA, responsible for the adhesion of proteins onto the cell membrane and connecting the proteins to form pili, was studied at a concentration of $2 \%$ QAS dilution and exhibited significant reduction with an IC50 value of $3.3 \pm 2.7 \mu \mathrm{M}$, a more potent value as compared to polyhexamethylene biguanide taken as positive control, IC50 $=24.5 \pm 4.1 \mu \mathrm{M}$ [191].

In a study conducted by Ooi et al., two distinct QACs having a dicationic porphyrin core, XF-70 (23a) and XF-73 (23b), were evaluated for their disruption of S. aureus biofilms. Both analogues entirely disrupted preformed $S$. aureus biofilms at a concentration of $2.6 \mu \mathrm{M}[192,193]$. The analogue XF-73 is currently being developed as a topical preparation by Destiny Pharma (Brighton, UK) and has started with a phase-II trial to assess its effect on patients with post surgical Staphylococcal nasal infestation. A phase-I trial of XF73 has shown noteworthy positive results [194]. Murakami et al. evaluated the effectiveness of $4,4^{\prime}-(\alpha, \omega$-hexamethylenedithio) bis (1-octylpyridinium bromide) (4DTBP-6,8) commonly known as gemini QACs a seventh generation BisQACs as an antibacterial and antibiofilm agent towards P. aeruginosa. A susceptibility assay for biofilm cells was performed which 
showed the numbers of surviving cells with cetylpyridinium chloride and benzalkonium chloride used as reference was 984- and 186- fold higher compared to cells treated with 4DTBP-6,8 (24) (Figure 11) [195].

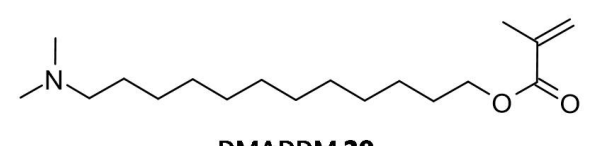

DMADDM 20<smiles>C=C(C)C(=O)OCCCCCCCCCCCCCCCCN(C)C</smiles>

DMADDM 21

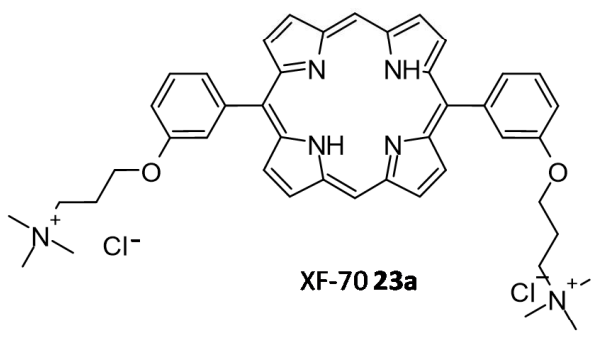

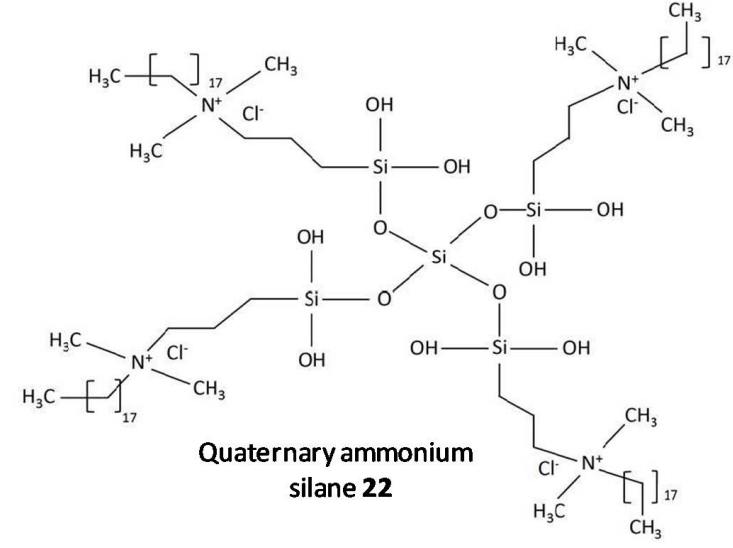

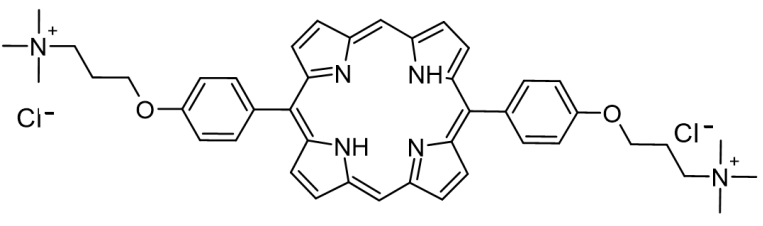

$\mathrm{XF}-7323 \mathrm{~b}$

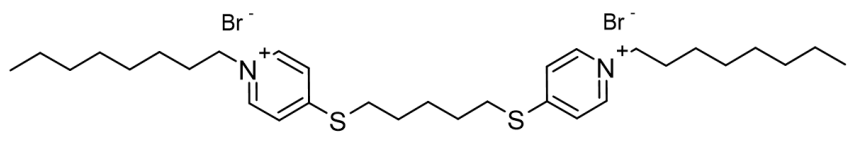

4DTBP-6,8 24

Figure 11. Chemical structures of some quaternary ammonium compounds.

\subsection{Natural Compounds}

Dong et al. evaluated resveratrol as a biofilm inhibitor against Aeromonas hydrophila. The significant reduction in biofilm formation using resveratrol (25) was noted at concentrations higher than $0.25 \mu \mathrm{g} / \mathrm{mL}$ and a $49.11 \%$ reduction in biofilm biogenesis was observed with $4 \mu \mathrm{g} / \mathrm{mL}$ [196]. Oh et al. investigated Raffinose (26), which is a $\alpha$-galactosyl derivatives of sucrose, and their isolate from ginger extract and evaluated for their ability to prevent biofouling in membrane bioreactors involved in membrane filtration and treatment of waste water. It was observed that the extract significantly reduced $25-52 \%$ of the P. aeruginosa and S. aureus co-culture biofilms at a concentration range of $0-1000 \mu \mathrm{M}$. In addition, Raffinose also decreased the transmembrane pressure in lab-scale membrane bioreactors compared to furanone C-30 used as control [197].

In a study by Husain et al., Pseudomonas species producing metallo-b-lactamase (MbLs) enzymes from camel meat were isolated and evaluated for their ability to form biofilms. Additionally, the effect of the flavone naringin (27) on the biogenesis of biofilm against the isolated Pseudomonas species was assessed by in silico and in vitro studies. A total of $55 \%$ isolates were found to produce MbLs. Naringin attenuated up to $57 \%$ of the biofilm formation in the isolated Pseudomonas species. Naringin remarkably turned down biofilms EPS and alginate density. Disruption of preformed biofilms from $32-60 \%$ was seen at respective $0.50 \mathrm{MICs}$. Naringin can thus be explored as a promising food preservative against foodborne Pseudomonas species forming biofilms [198].

In recent work by Lyu et al. the biofilm inhibition ability of ursolic acid (28) was evaluated towards oral Streptococci species. Ursolic acid being a natural product can be derived from plant parts such as privet leaves, berries, loquat leaf, paulownia leaves and 
iron holly. It was observed that ursolic acid inhibits multi-species biofilms of $S$. mutans, S. gordonii and S. sanguinis at a concentration of $7.80 \mu \mathrm{g} / \mathrm{mL}$. Moreover they inhibited specifically glucosyltransferases the prime cariogenic component of oral biofilms and displayed relatively less cytotoxicity towards human oral cells [199]. Wei et al. and Pun et al. recently investigated the outcome of phloretin (29) on Listeria monocytogenes biofilm formation. Phloretin in sub-MIC levels was used at different temperatures of $37{ }^{\circ} \mathrm{C}$ and $4{ }^{\circ} \mathrm{C}$ to treat the biofilm. It showed maximum inhibition of the biofilm up to $60 \%$ with a concentration of $20 \mu \mathrm{g} / \mathrm{mL}$. Moreover, the amount of biofilm aggregation and adhesion in L. monocytogenes was subsequently diminished. The thickness of the biofilm was lessened by $2 \mu \mathrm{m}$ at a concentration of $20 \mu \mathrm{g} / \mathrm{mL}$. The mode of biofilm inhibition study revealed the role of phloretin reducing the QS related gene agr by $50 \%$ with $20 \mu \mathrm{g} / \mathrm{mL}$ phloretin [200,201].

Wang et al. investigated Baicalin (30), a natural compound derived from the roots of Scutellaria baicalensis, and evaluated its ability to inhibit biofilm formation in Staphylococcus saprophyticus and its QS by selectively inhibiting the MsrA drug efflux pump. The study displayed promising results with baicalin decreasing biofilm biogenesis, and bacterial aggregation by downstreaming the mRNA transcription proportion of the QS regulators agrA, agrC, sarA and RNAIII [202,203].

Reis et al. evaluated three flavonoids from Brosimum acutifolium, 4'-hydroxy-7,8(2", $2^{\prime \prime}$ dimethylpyran) flavan (31), brosimine b (32) and 4-hydroxy-lonchocarpin (33), as antibiofilm agents. $\mathrm{A}$ and $\mathrm{B}$ decreased the viability in preformed $S$. aureus biofilms upto $73 \%$ at a concentration of $50 \mu \mathrm{M}$. Additionally, B decreased the biofilm biomass upto $48 \%$ at a concentration of $100 \mu \mathrm{M}$ whereas $\mathrm{C}$ was unable to reduce the biofilm biomass. B at a concentration of $100 \mu \mathrm{M}$ curbed $70-98 \%$ of planktonic cells in a 24-old MRSA biofilm (Figure 12) [204].

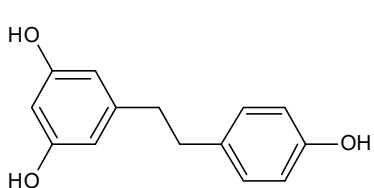

Resveratrol 25

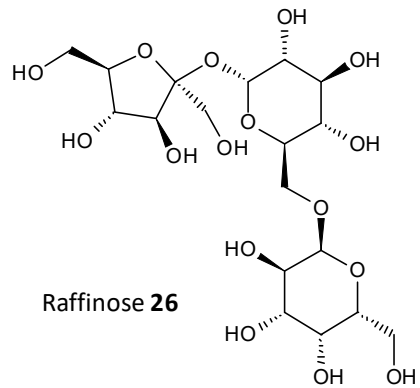

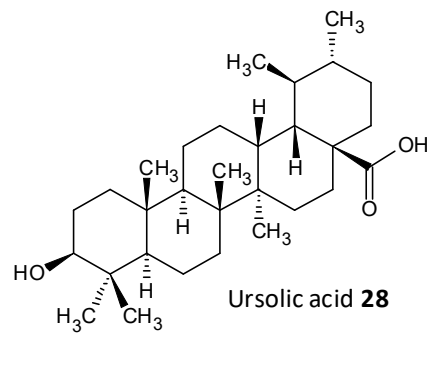<smiles>C/C=C(\C)C1CC(O)c2c(O)cc(O[C@@H]3O[C@H](CO)[C@@H](O)[C@H](O)[C@H]3CC3O[C@H](C)[C@@H](O)[C@H](O)[C@H]3O)cc2O1</smiles>

Naringin 27<smiles>O=C(CCc1ccc(O)cc1)c1c(O)cc(O)cc1O</smiles>

Phloretin 29<smiles>O=C(O)[C@H]1C[C@@H](Oc2cc3oc(-c4ccccc4)cc(=O)c3c(O)c2O)[C@H](O)[C@H](O)[C@@H]1O</smiles>

Baicalin 30

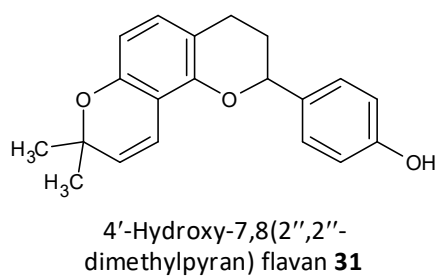<smiles>CC(C)=CCc1c(O)ccc2c1OC(c1ccc(O)cc1)CC2</smiles><smiles>CC1(C)C=Cc2c(ccc(CCCc3ccc(O)cc3)c2O)O1</smiles>

4-Hydroxy-lonchocarpin 33

Figure 12. Chemical structures of some natural antibiofilm agents. 


\section{Investigative Strategies to Eradicate Biofilms}

The emergence of resistance to existing clinical antimicrobials and the high dose regime required to curb biofilm associated infection conditions, and the paucity of a consummate antibiofilm therapy necessitates the need for novel strategies to thoroughly eradicate biofilms. Some burgeoning strategies are highlighted in this review (Figure 13).

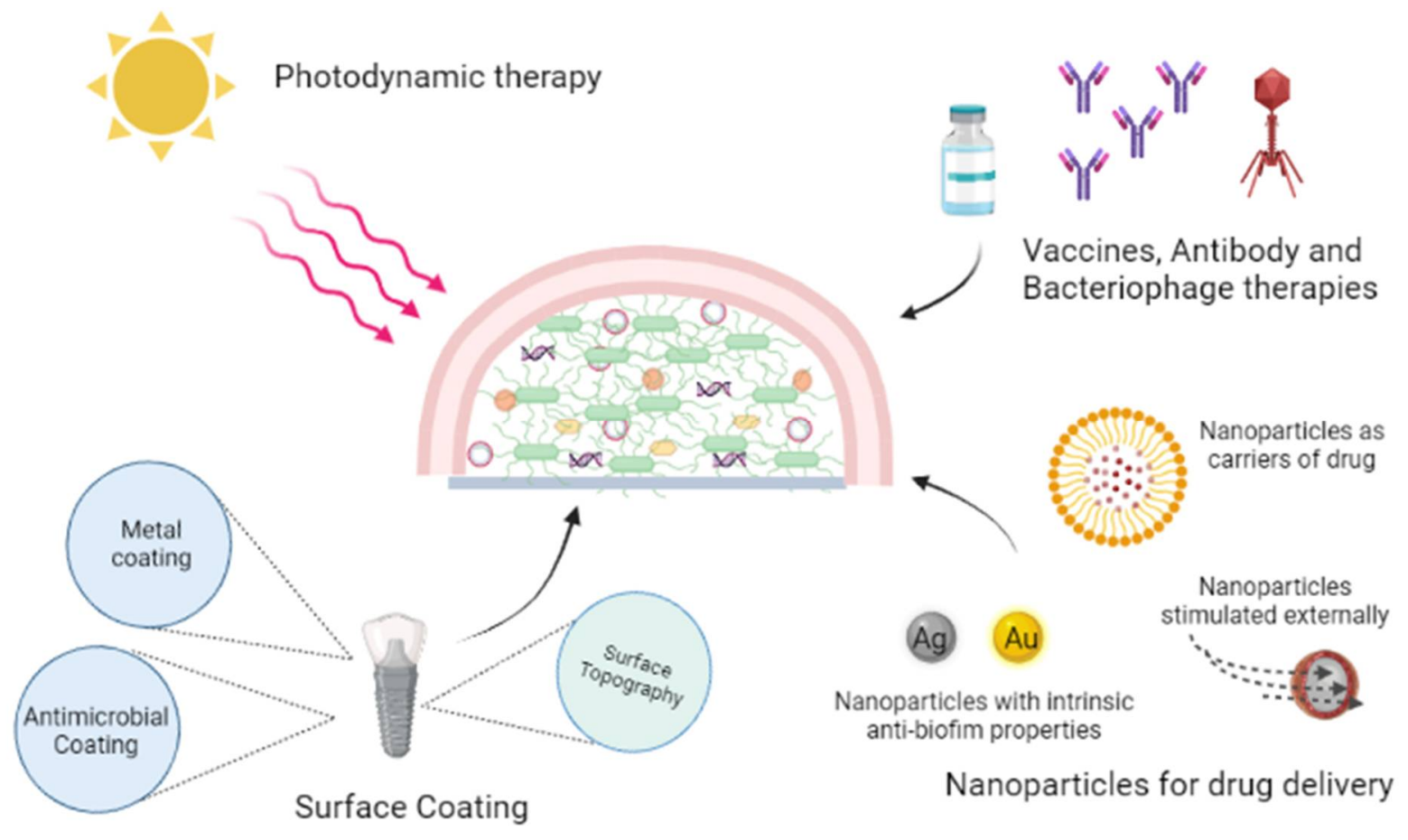

Figure 13. Investigative strategies to eradicate biofilms.

\subsection{Photodynamic Therapy}

Photodynamic therapy (PDT) has prospective use in elimination of biofilm infections associated with surface wounds. In PDT mild visible light of specific wavelength is used along with innocuous photosensitizers to form cytotoxic reactive oxygen species (ROS) thus killing the bacteria. In a study conducted by Ronqui et al., synergistic therapy of PDT followed by ciprofloxacin treatment exhibited a remarkable reduction of biofilms, with a 5.4 and $7 \log$ reduction for S. aureus and E. coli biofilms, respectively. Hypericinloaded nanoparticles combined with PDT has been investigated, the study showed that PDT treatment offered quick wound healing and formation of collagen fibers in rats. In PDT appropriate care should be taken to avoid exposure of a patient's eyes to the laser light [205-208].

\subsection{Antibodies and Macrophages}

Antibodies targeted towards bacterial surface attachment, if used prophylactically, can prevent biofilm biogenesis [209,210]. A human monoclonal antibody mAb 3H3, was assessed by Tursi et al. for its pan-amyloid binding ability. The antibody disrupted biofilms formed by S. typhimurium and eventually enhanced the efficacy of antibiotic treatment in vivo. In mice, a $3 \mathrm{H} 3$ injection showed antibiotic conciliated clearance of S. typhimurium biofilms in catheters [211-214]. Sun et al. used a mixture of two MAbs, $12 \mathrm{C} 6 / 12 \mathrm{~A} 1$ and $3 \mathrm{C} 1 / 12 \mathrm{~A} 1$, which synergistically reduced the attachment and accumulation of S. epidermidis up to $87 \%$ [215]. A cocktail of macrophages has the ability to avert Proteus mirabilis biofilms formed on catheters [216]. Additionally, macrophages could eliminate $P$. aeruginosa biofilms in murine model lungs and eradicate biofilms formed in wounds associated to S. aureus [217]. A phage lysin has proven to be efficacious in eradicating biofilms by fundamentally cleaving the bacterial cell and also effective towards 
persister cells. Recombinant exebacase (Lysin CF-301) for treatment of MRSA endocarditis and bacteraemia in synergism with some antibiotics is now in clinical trials [218-220]. The stumbling block with macrophage treatment is the resistance formed and their swift clearance by the host immune response. The spatially architectural community of the biofilm allows the dwelling of phage-sensitive bacteria.

\subsection{Surface Coating or Modification}

The multipurpose surface topography and coating on implants are considered as an innovative way to fight against biofilm formation and with the recent emergence in the field of surface engineering new hopes are seen in this arena. The newer techniques like nanoimprint lithography, electron beam and colloidal lithography are utilized for fabrication of textured biomaterial nanosurfaces [221,222]. Coating the implants superficially helps attain the desired outcome without altering the original materials characteristics. Preventing bacterial adhesion, interfering with biofilm formation, and inactivation of the biofilm are the major strategies used in the design of antibacterial coatings. Electrophoretic, chemical vapor and physical vapor deposition are widely used to form uniform thin films on different implants. Recently, AMPs have exhibited inhibition of biofilms and have been used to coat silicon, stainless steel, titanium, glass surfaces, and polystyrene [223-225]. Also, antibiotic coating with different classes of antimicrobials like beta-lactam antibiotics, aminoglycosides, rifamycins, and quinolones are explored. Enzymes inhibiting QS are used for coating which includes enzymes such as acylase, oxidase, and lactonase [226-228]. Methacrylic copolymer films loaded with a combination of the antibiotics rifampin, clarithromycin and doxycycline efficiently released the drugs for 21 days and prevented formation of biofilms of MRSA, and a combination of clarithromycin with rifampin was able to kill more than $99.9 \%$ of MRSA strains. Combinatory antibiotic therapy provides a good opportunity to bridle the antimicrobial resistance observed with single antibiotics $[229,230]$. A drawback in the coating strategy is the expeditious eroding of the coating material with time.

\subsection{Nanoparticle Systems}

Owing to the poor permeability concerns coupled with the available drugs towards the persister cells, nanoparticle (NP) delivery systems can be explored for localized drug delivery of antimicrobial agents into biofilms. As evident by several reports, silver nanoparticles (AgNPs) have intrinsic bacteriocidal property and are proven to eradicate biofilms. Siddique et al. studied AgNPs and evaluated their biofilm inhibition against two strains of K. pneumoniae. The percent biofilm inhibition was found to be $64 \%$ and $86 \%$ for K. pneumoniae MF953600 and MF953599, respectively at $100 \mu \mathrm{g} / \mathrm{mL}$ concentration [231]. Additionally, the formation of EPS was reduced on treatment with AgNPs and caused cellular membrane disruption. In a similar work by Hetta et al. the biofilm inhibitory activity and antivirulence ability of AgNPs was assessed towards multidrug-resistant $A$. baumannii. The results showed a downregulation in expression of virulence and biofilm-related genes like afa/draBC, kpsMII, ompA, bap, and csuA/B by AgNPs [232]. Recently, Singh et al. studied synthesis of Ag and Au NPs from Cannabis sativa and explored their biofilm inhibitory effect towards P. aeruginosa and E. coli at a concentration range of $1.6-100 \mu \mathrm{g} / \mathrm{mL}$. AgNPs displayed superior inhibition of biofilm formation even at sub-MIC level [233].

Gounani et al. recently designed tailor-made mesoporous silica NPs as a carrier for the antibiotic vancomycin using surface functionality like amine, carboxyl or aromatic groups. The cellular affinity and attachment with mesoporous silica NP suspensions $0.25 \mathrm{mg} / \mathrm{mL}$ was related to a decrease in growth of MRSA biofilm cells [234,235].

A new nanohybrid complex of $\mathrm{Ag}$ and iron oxide was designed and subjected to a magnetic field by Sangili et al. These magnetically responsive NPs responded remarkably well compared to bare nanohybrid complexes in disrupting biofilms of $E$. coli and P. aeruginosa with inhibitions of $88 \%$ and $90 \%$, respectively [236,237]. Abenojar et al. designed a thermoresponsive glycol chitin-based nanocomposite composed of iron oxide nanoparticles and D-amino acids, which transformed from a solution to a gel at physiologi- 
cal temperature with release of D-amino acids. Following the initial disruption by D-amino acids, the nanocomposites combined with thermal treatment were actuated by an external magnetic field to achieve complete disruption of $S$. aureus biofilms [238,239]].

The intricacy in the structure of the biofilms makes the antibiotics difficult to target the bacteria and emergence of resistance to them. Unlike traditional antibiotics, NPs have peculiar dimensions of $<100 \mathrm{~nm}$, making them an apt carrier for the antibiotics. These NPs due to their size, help to selectively target the antibiotics to the infestation site thereby lowering the detrimental systemic adverse effects. The NPs exhibit their antimicrobial activity fundamentally by following mechanisms like disrupting the cell membrane and generating ROS. The ROS sequentially initiate intracellular effects by interacting with DNA, ribosomes, enzyme causing oxidative stress associated protein denaturation, DNA damage, ribosomal disassembly and inhibiting cell-to-cell communication within the cell (Figure 14). AgNPs have been shown to induce neutralization of the bacterial membrane surface charges thereby altering its penetrability, eventually leading to cell apoptosis [240,241].

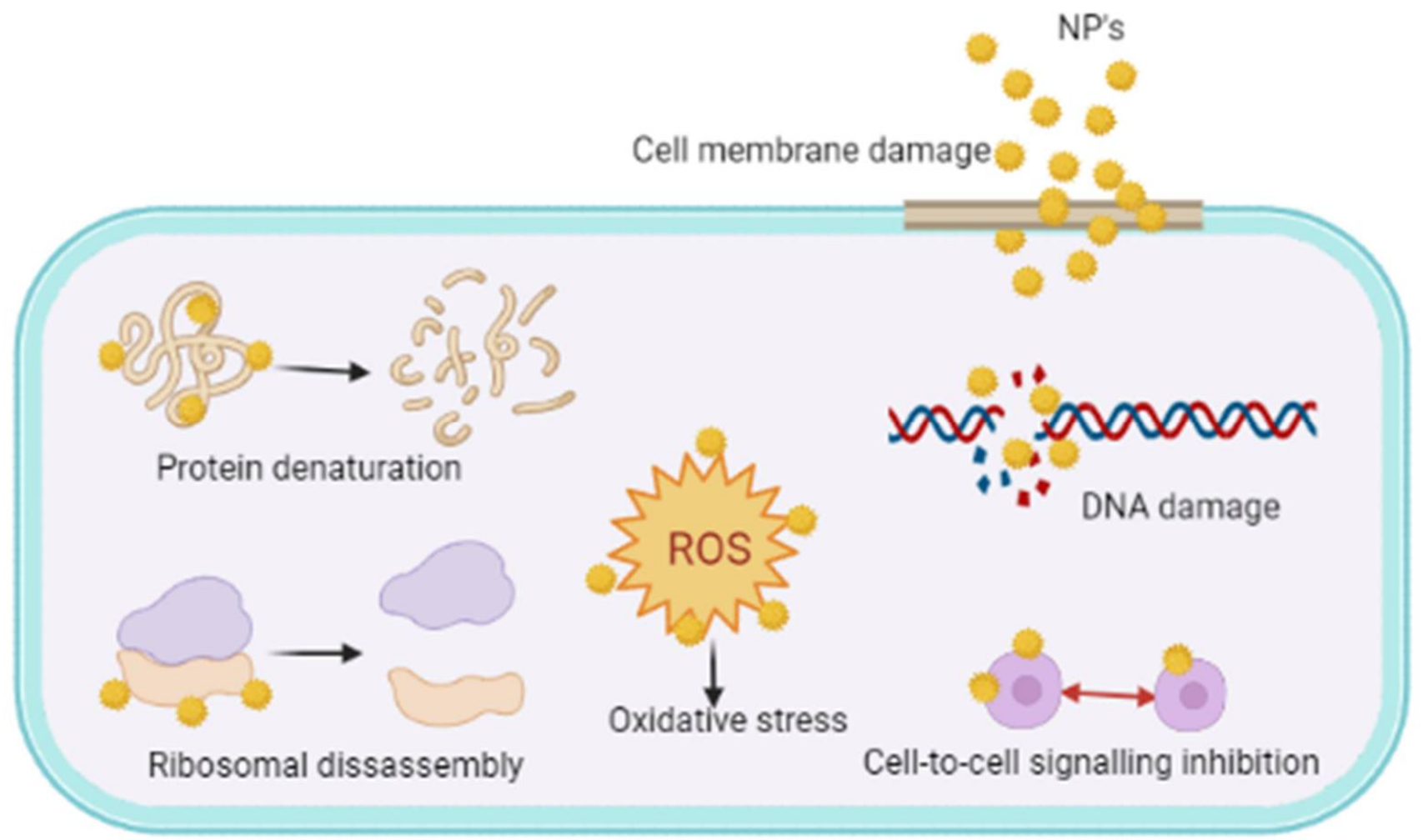

Figure 14. Mechanisms of antibiofilm activities of nanoparticles.

\section{Conclusions and Future Perspectives}

A majority of bacteria found in the environment dwell in the form of sessile biofilms. A careful insight about the complex biofilm biology, its formation process and mode of action aids the design of new antibiofilm agents and strategies. Owing to the hallmark inherent recalcitrance shown by biofilms towards clinically used antimicrobials and the fact that biofilm associated infestations are extremely difficult to treat, there is need for newer antibiofilm agents. Understanding the mode of action of antibiofilm agents provides a roadmap to fill the opportunities in the field. Small-molecule chemical agents hold "drug"like characteristics and have proven to act against several strains of bacteria resistant to existing antibiotics. QS inhibitors can curb pathogenic infection by blocking cell-to-cell communication and opening up an arsenal for treating biofilm related infections. AMPs have gained interest for their multimodal mechanism of action and reduced the chances of developing resistance. The major pitfall in the use of AMPs is their quick deterioration by several bacterial proteases. QACs have gained notoriety for mimicking the role of the 
AMPs without undergoing degradation and their inherently small structure comparative to AMPs. The use of naturally derived bioactives have gained immense popularity as biofilm inhibitors owing to their associated safety. Natural phytochemicals in combination with commercial antimicrobials needs to be explored as an alternate strategy to win over the ongoing war against AMR by biofilms. Several novel techniques have been explored for dismantling the biofilm and its related infections.

Author Contributions: S.N. and T.K. performed the research and wrote the first draft of the manuscript. S.N., T.K. and S.G.P. prepared the tables and figures. S.G.P. and A.O. revised and expanded the first draft of the manuscript and revised the manuscript following reviewer comments and requests. All authors read, corrected and approved the final version of the manuscript. S.G.P. and A.O. coordinated the work and submission of the manuscript. All authors have read and agreed to the published version of the manuscript.

Funding: This research received no external funding.

Institutional Review Board Statement: Not applicable.

Informed Consent Statement: Not applicable.

Data Availability Statement: Not applicable.

Conflicts of Interest: The authors declare no conflict of interest.

\section{References}

1. Høiby, N. A short history of microbial biofilms and biofilm infections. APMIS 2017, 125, 272-275. [CrossRef] [PubMed]

2. Flemming, H.C.; Wuertz, S. Bacteria and archaea on Earth and their abundance in biofilms. Nat. Rev. Microbiol. 2019, 17, 247-260. [CrossRef] [PubMed]

3. Vasudevan, R. Biofilms: Microbial cities of scientific significance. J. Microbiol. Exp. 2014, 1, 84-98. [CrossRef]

4. Martens, E.; Demain, A.L. The antibiotic resistance crisis, with a focus on the United States. J. Antibiot. 2017, 70, 520-526. [CrossRef] [PubMed]

5. Bjarnsholt, T. The role of bacterial biofilms in chronic infections. APMIS Suppl. 2013, 136, 1-51. [CrossRef] [PubMed]

6. Gellatly, S.L.; Hancock, R.E. Pseudomonas aeruginosa: New insights into pathogenesis and host defenses. Pathog. Dis. 2013, 67, 159-173. [CrossRef] [PubMed]

7. Fey, P.D.; Olson, M.E. Current concepts in biofilm formation of Staphylococcus epidermidis. Future Microbiol. 2010, 5, 917-933. [CrossRef]

8. Ch'ng, J.H.; Chong, K.K.L.; Lam, L.N.; Wong, J.J.; Kline, K.A. Biofilm-associated infection by enterococci. Nat. Rev. Microbiol. 2019, 17, 82-94. [CrossRef]

9. Zheng, J.X.; Bai, B.; Lin, Z.W.; Pu, Z.Y.; Yao, W.M.; Chen, Z.; Li, D.Y.; Deng, X.B.; Deng, Q.W.; Yu, Z.J. Characterization of biofilm formation by Enterococcus faecalis isolates derived from urinary tract infections in China. J. Med. Microbiol. 2018, 67, 60-67. [CrossRef]

10. Kristich, C.J.; Li, Y.H.; Cvitkovitch, D.G.; Dunny, G.M. Esp-independent biofilm formation by Enterococcus faecalis. J. Bacteriol. 2004, 186, 154-163. [CrossRef]

11. Gordon, R.J.; Lowy, F.D. Pathogenesis of methicillin-resistant Staphylococcus aureus infection. Clin. Infect. Dis. 2008, 46, S350-S359. [CrossRef] [PubMed]

12. Archer, N.K.; Mazaitis, M.J.; Costerton, J.W.; Leid, J.G.; Powers, M.E.; Shirtliff, M.E. Staphylococcus aureus biofilms: Properties, regulation, and roles in human disease. Virulence 2011, 2, 445-459. [CrossRef] [PubMed]

13. Lister, J.L.; Horswill, A.R. Staphylococcus aureus biofilms: Recent developments in biofilm dispersal. Front. Cell Infect. Microbiol. 2014, 4, 178. [CrossRef] [PubMed]

14. Kong, C.; Chee, C.F.; Richter, K.; Thomas, N.; Abd Rahman, N.; Nathan, S. Suppression of Staphylococcus aureus biofilm formation and virulence by a benzimidazole derivative, UM-C162. Sci. Rep. 2018, 8, 2758. [CrossRef]

15. Piperaki, E.T.; Syrogiannopoulos, G.A.; Tzouvelekis, L.S.; Daikos, G.L. Klebsiella pneumoniae: Virulence, biofilm and antimicrobial resistance. Pediatr. Infect. Dis. J. 2017, 36, 1002-1005. [CrossRef]

16. Zheng, J.X.; Lin, Z.W.; Chen, C.; Chen, Z.; Lin, F.J.; Wu, Y.; Yang, S.Y.; Sun, X.; Yao, W.M.; Li, D.Y.; et al. Biofilm formation in Klebsiella pneumoniae bacteremia strains was found to be associated with CC23 and the presence of wcaG. Front. Cell Infect. Microbiol. 2018, 8, 21. [CrossRef]

17. Nirwati, H.; Sinanjung, K.; Fahrunissa, F.; Wijaya, F.; Napitupulu, S.; Hati, V.P.; Hakim, M.S.; Meliala, A.; Aman, A.T.; Nuryastuti, T. Biofilm formation and antibiotic resistance of Klebsiella pneumoniae isolated from clinical samples in a tertiary care hospital, Klaten, Indonesia. BMC Proc. 2019, 13, 20. [CrossRef]

18. Loo, C.Y.; Corliss, D.A.; Ganeshkumar, N. Streptococcus gordonii biofilm formation: Identification of genes that code for biofilm phenotypes. J. Bacteriol. 2000, 182, 1374-1382. [CrossRef] 
19. Haslam, D.B.; St. Geme, J.W. 121-Viridans Streptococci, Abiotrophia and Granulicatella Species, and Streptococcus bovis Group. In Principles and Practice of Pediatric Infectious Diseases, 5th ed.; Long, S.S., Prober, C.G., Fischer, M., Eds.; Elsevier: Philadelphia, PA, USA, 2018; pp. 732-735.e1.

20. Presterl, E.; Grisold, A.J.; Reichmann, S.; Hirschl, A.M.; Georgopoulos, A.; Graninger, W. Viridans streptococci in endocarditis and neutropenic sepsis: Biofilm formation and effects of antibiotics. J. Antimicrob. Chemother. 2005, 55, 45-50. [CrossRef]

21. Yadav, P.; Verma, S.; Bauer, R.; Kumari, M.; Dua, M.; Johri, A.K.; Yadav, V.; Spellerberg, B. Deciphering Streptococcal biofilms. Microorganisms 2020, 8, 1835. [CrossRef]

22. Sharma, G.; Sharma, S.; Sharma, P.; Chandola, D.; Dang, S.; Gupta, S.; Gabrani, R. Escherichia coli biofilm: Development and therapeutic strategies. J. Appl. Microbiol. 2016, 121, 309-319. [CrossRef] [PubMed]

23. Beloin, C.; Roux, A.; Ghigo, J.M. Escherichia coli biofilms. Curr. Top. Microbiol. Immunol. 2008, 322, 249-289. [PubMed]

24. Czerwonka, G.; Guzy, A.; Kałuża, K.; Grosicka, M.; Dańczuk, M.; Lechowicz, Ł.; Gmiter, D.; Kowalczyk, P.; Kaca, W. The role of Proteus mirabilis cell wall features in biofilm formation. Arch. Microbiol. 2016, 198, 877-884. [CrossRef] [PubMed]

25. Wasfi, R.; Hamed, S.M.; Amer, M.A.; Fahmy, L.I. Proteus mirabilis biofilm: Development and therapeutic strategies. Front. Cell Infect. Microbiol. 2020, 10, 414. [CrossRef] [PubMed]

26. Orazi, G.; O'Toole, G.A. "It takes a village": Mechanisms underlying antimicrobial recalcitrance of polymicrobial biofilms. $J$. Bacteriol. 2019, 202, e00530-19. [CrossRef] [PubMed]

27. Aggarwal, S.; Stewart, P.S.; Hozalski, R.M. Biofilm cohesive strength as a basis for biofilm recalcitrance: Are bacterial biofilms overdesigned? Microbiol. Insights 2016, 8, 29-32. [CrossRef] [PubMed]

28. Boudarel, H.; Mathias, J.D.; Blaysat, B.; Grédiac, M. Towards standardized mechanical characterization of microbial biofilms: Analysis and critical review. NPJ Biofilms Microbiomes 2018, 4, 17. [CrossRef]

29. Balaure, P.C.; Grumezescu, A.M. Recent advances in surface nanoengineering for biofilm prevention and control. Part I: Molecular basis of biofilm recalcitrance. Passive anti-biofouling nanocoatings. Nanomaterials 2020, 10, 1230. [CrossRef]

30. Hall, C.W.; Mah, T.F. Molecular mechanisms of biofilm-based antibiotic resistance and tolerance in pathogenic bacteria. FEMS Microbiol. Rev. 2017, 41, 276-301. [CrossRef]

31. Lebeaux, D.; Ghigo, J.M.; Beloin, C. Biofilm-related infections: Bridging the gap between clinical management and fundamental aspects of recalcitrance toward antibiotics. Microbiol. Mol. Biol. Rev. 2014, 78, 510-543. [CrossRef]

32. Talsma, S.S. Biofilms on medical devices. Home Healthc. Nurse 2007, 25, 589-594. [CrossRef]

33. Khatoon, Z.; McTiernan, C.D.; Suuronen, E.J.; Mah, T.F.; Alarcon, E.I. Bacterial biofilm formation on implantable devices and approaches to its treatment and prevention. Heliyon 2018, 4, e01067. [CrossRef] [PubMed]

34. Francolini, I.; Donelli, G. Prevention and control of biofilm-based medical-device-related infections. FEMS Immunol. Med. Microbiol. 2010, 59, 227-238. [CrossRef] [PubMed]

35. Costerton, J.W.; Montanaro, L.; Arciola, C.R. Biofilm in implant infections: Its production and regulation. Int. J. Artif. Organs 2005, 28, 1062-1068. [CrossRef] [PubMed]

36. Percival, S.L.; Suleman, L.; Vuotto, C.; Donelli, G. Healthcare-associated infections, medical devices and biofilms: Risk, tolerance and control. J. Med. Microbiol. 2015, 64, 323-334. [CrossRef]

37. Connaughton, A.; Childs, A.; Dylewski, S.; Sabesan, V.J. Biofilm disrupting technology for orthopedic implants: What's on the horizon? Front. Med. 2014, 1, 22. [CrossRef]

38. Busscher, H.J.; Rinastiti, M.; Siswomihardjo, W.; van der Mei, H.C. Biofilm formation on dental restorative and implant materials. J. Dent. Res. 2010, 89, 657-665. [CrossRef]

39. Larsen, T.; Fiehn, N.E. Dental biofilm infections-An update. APMIS 2017, 125, 376-384. [CrossRef]

40. Dhaliwal, J.S.; Abd Rahman, N.A.; Ming, L.C.; Dhaliwal, S.K.S.; Knights, J.; Albuquerque Junior, R.F. Microbial biofilm decontamination on dental implant surfaces: A mini review. Front. Cell Infect. Microbiol. 2021, 11, 736186. [CrossRef]

41. Stoitsova, S.R.; Paunova-Krasteva, T.S.; Borisova, D.B. Modulation of biofilm growth by sub-inhibitory amounts of antibacterial substances. In Microbial Biofilms: Importance and Applications; IntechOpen: London, UK, 2016. [CrossRef]

42. Ranieri, M.R.; Whitchurch, C.B.; Burrows, L.L. Mechanisms of biofilm stimulation by subinhibitory concentrations of antimicrobials. Curr. Opin. Microbiol. 2018, 45, 164-169. [CrossRef]

43. Vasilchenko, A.S.; Rogozhin, E.A. Sub-inhibitory effects of antimicrobial peptides. Front. Microbiol. 2019, 10, 1160. [CrossRef] [PubMed]

44. Kowalska-Krochmal, B.; Dudek-Wicher, R. The minimum inhibitory concentration of antibiotics: Methods, interpretation, clinical relevance. Pathogens 2021, 10, 165. [CrossRef] [PubMed]

45. Bernardi, S.; Anderson, A.; Macchiarelli, G.; Hellwig, E.; Cieplik, F.; Vach, K.; Al-Ahmad, A. Subinhibitory antibiotic concentrations enhance biofilm formation of clinical Enterococcus faecalis isolates. Antibiotics 2021, 10, 874. [CrossRef] [PubMed]

46. Donlan, R.M. Biofilm formation: A clinically relevant microbiological process. Clin. Infect. Dis. 2001, 33, 1387-1392. [CrossRef] [PubMed]

47. Floyd, K.A.; Eberly, A.R.; Hadjifrangiskou, M. 3-Adhesion of bacteria to surfaces and biofilm formation on medical devices. In Biofilms and Implantable Medical Devices; Deng, Y., Lv, W., Eds.; Woodhead Publishing: Cambridge, UK, 2017 ; pp. 47-95.

48. Berne, C.; Ducret, A.; Hardy, G.G.; Brun, Y.V. Adhesins involved in attachment to abiotic surfaces by Gram-negative bacteria. Microbiol. Spectr. 2015, 3. [CrossRef] [PubMed] 
49. Finlay, B.B.; Caparon, M. Bacterial adherence to cell surfaces and extracellular matrix. In Cellular Microbiology; Cossart, P., Bouquet, P., Normark, S., Rappuoli, R., Eds.; American Society for Microbiology Press: Washington, DC, USA, 2004; pp. 105-120.

50. Lee, C.K.; de Anda, J.; Baker, A.E.; Bennett, R.R.; Luo, Y.; Lee, E.Y.; Keefe, J.A.; Helali, J.S.; Ma, J.; Zhao, K.; et al. Multigenerational memory and adaptive adhesion in early bacterial biofilm communities. Proc. Natl. Acad. Sci. USA 2018, 115, 4471-4476. [CrossRef]

51. Armbruster, C.R.; Parsek, M.R. New insight into the early stages of biofilm formation. Proc. Natl. Acad. Sci. USA 2018, 115, 4317-4319. [CrossRef]

52. Johnson, L.R. Microcolony and biofilm formation as a survival strategy for bacteria. J. Theor. Biol. 2008, 251, 24-34. [CrossRef]

53. Petrova, O.E.; Schurr, J.R.; Schurr, M.J.; Sauer, K. Microcolony formation by the opportunistic pathogen Pseudomonas aeruginosa requires pyruvate and pyruvate fermentation. Mol. Microbiol. 2012, 86, 819-835. [CrossRef]

54. Sriramulu, D.D.; Lünsdorf, H.; Lam, J.S.; Römling, U. Microcolony formation: A novel biofilm model of Pseudomonas aeruginosa for the cystic fibrosis lung. J. Med. Microbiol. 2005, 54, 667-676. [CrossRef]

55. Hooshdar, P.; Kermanshahi, R.K.; Ghadam, P.; Darani, K.K. A review on production of exopolysaccharide and biofilm in probiotics like Lactobacilli and methods of analysis. Biointerface Res. Appl. Chem. 2020, 10, 6058-6075.

56. Flemming, H.C.; Wingender, J. The biofilm matrix. Nat. Rev. Microbiol. 2010, 8, 623-633. [CrossRef] [PubMed]

57. Decho, A.W.; Gutierrez, T. Microbial extracellular polymeric substances (EPSs) in ocean systems. Front. Microbiol. 2017, $26,922$. [CrossRef] [PubMed]

58. Nishanth, S.; Bharti, A.; Gupta, H.; Gupta, K.; Gulia, U.; Prasanna, R. Cyanobacterial extracellular polymeric substances (EPS): Biosynthesis and their potential applications. In Microbial and Natural Macromolecules Synthesis and Applications; Das, S., Dash, H.R., Eds.; Academic Press: London, UK, 2021; pp. 349-369.

59. Limoli, D.H.; Jones, C.J.; Wozniak, D.J. Bacterial extracellular polysaccharides in biofilm formation and function. Microbiol. Spectr 2015, 3. [CrossRef]

60. Karygianni, L.; Ren, Z.; Koo, H.; Thurnheer, T. Biofilm matrixome: Extracellular components in structured microbial communities. Trends Microbiol. 2020, 28, 668-681. [CrossRef]

61. Costa, O.Y.A.; Raaijmakers, J.M.; Kuramae, E.E. Microbial extracellular polymeric substances: Ecological function and impact on soil aggregation. Front. Microbiol. 2018, 9, 1636. [CrossRef]

62. Lembre, P.; Lorentz, C.; Martino, P.D. Exopolysaccharides of the biofilm matrix: A complex biophysical world. In The Complex World of Polysaccharides; Karunaratne, D.N., Ed.; IntechOpen: London, UK, 2012; pp. 371-392.

63. Maunders, E.; Welch, M. Matrix exopolysaccharides; the sticky side of biofilm formation. FEMS Microbiol. Lett. 2017, 364, fnx120. [CrossRef]

64. Dunsing, V.; Irmscher, T.; Barbirz, S.; Chiantia, S. Purely polysaccharide-based biofilm matrix provides size-selective diffusion barriers for nanoparticles and bacteriophages. Biomacromolecules 2019, 20, 3842-3854. [CrossRef]

65. Colvin, K.M.; Gordon, V.D.; Murakami, K.; Borlee, B.R.; Wozniak, D.J.; Wong, G.C.; Parsek, M.R. The pel polysaccharide can serve a structural and protective role in the biofilm matrix of Pseudomonas aeruginosa. PLoS Pathog. 2011, 7, e1001264. [CrossRef]

66. Cherny, K.E.; Sauer, K. Untethering and degradation of the polysaccharide matrix are essential steps in the dispersion response of Pseudomonas aeruginosa biofilms. J. Bacteriol. 2020, 202, e00575-19. [CrossRef]

67. Xavier, J.B.; Foster, K.R. Cooperation and conflict in microbial biofilms. Proc. Natl. Acad. Sci. USA 2007, 104, 876-881. [CrossRef] [PubMed]

68. Schooling, S.R.; Beveridge, T.J. Membrane vesicles: An overlooked component of the matrices of biofilms. J. Bacteriol. 2006, 188, 5945-5957. [CrossRef] [PubMed]

69. Karatan, E.; Watnick, P. Signals, regulatory networks, and materials that build and break bacterial biofilms. Microbiol. Mol. Biol. Rev. 2009, 73, 310-347. [CrossRef] [PubMed]

70. Wingender, J.; Neu, T.R.; Flemming, H.-C. What are bacterial extracellular polymeric substances? In Microbial Extracellular Polymeric Substances: Characterization, Structure and Function; Wingender, J., Neu, T.R., Flemming, H.-C., Eds.; Springer: Berlin/Heidelberg, Germany, 1999; pp. 1-19.

71. Arciola, C.R.; Campoccia, D.; Ravaioli, S.; Montanaro, L. Polysaccharide intercellular adhesin in biofilm: Structural and regulatory aspects. Front. Cell Infect. Microbiol. 2015, 5, 7. [CrossRef]

72. Vuong, C.; Voyich, J.M.; Fischer, E.R.; Braughton, K.R.; Whitney, A.R.; DeLeo, F.R.; Otto, M. Polysaccharide intercellular adhesin (PIA) protects Staphylococcus epidermidis against major components of the human innate immune system. Cell Microbiol. 2004, 6, 269-275. [CrossRef]

73. Gholami, S.A.; Goli, H.R.; Haghshenas, M.R.; Mirzaei, B. Evaluation of polysaccharide intercellular adhesion (PIA) and glycerol teichoic acid (Gly-TA) arisen antibodies to prevention of biofilm formation in Staphylococcus aureus and Staphylococcus epidermidis strains. BMC Res. Notes 2019, 12, 691. [CrossRef]

74. Colvin, K.M.; Irie, Y.; Tart, C.S.; Urbano, R.; Whitney, J.C.; Ryder, C.; Howell, P.L.; Wozniak, D.J.; Parsek, M.R. The Pel and Psl polysaccharides provide Pseudomonas aeruginosa structural redundancy within the biofilm matrix. Environ. Microbiol. 2012, 14, 1913-1928. [CrossRef]

75. Jennings, L.K.; Storek, K.M.; Ledvina, H.E.; Coulon, C.; Marmont, L.S.; Sadovskaya, I.; Secor, P.R.; Tseng, B.S.; Scian, M.; Filloux, A.; et al. Pel is a cationic exopolysaccharide that cross-links extracellular DNA in the Pseudomonas aeruginosa biofilm matrix. Proc. Natl. Acad. Sci. USA 2015, 112, 11353-11358. [CrossRef] 
76. Franklin, M.J.; Nivens, D.E.; Weadge, J.T.; Howell, P.L. Biosynthesis of the Pseudomonas aeruginosa extracellular polysaccharides, alginate, Pel, and Psl. Front. Microbiol. 2011, 2, 167. [CrossRef]

77. Zegans, M.E.; Wozniak, D.; Griffin, E.; Toutain-Kidd, C.M.; Hammond, J.H.; Garfoot, A.; Lam, J.S. Pseudomonas aeruginosa exopolysaccharide Psl promotes resistance to the biofilm inhibitor polysorbate 80. Antimicrob. Agents Chemother. 2012, 56, 4112-4122. [CrossRef]

78. Wozniak, D.J.; Wyckoff, T.J.; Starkey, M.; Keyser, R.; Azadi, P.; O’Toole, G.A.; Parsek, M.R. Alginate is not a significant component of the extracellular polysaccharide matrix of PA14 and PAO1 Pseudomonas aeruginosa biofilms. Proc. Natl. Acad. Sci. USA 2003, 100, 7907-7912. [CrossRef] [PubMed]

79. Laue, H.; Schenk, A.; Li, H.; Lambertsen, L.; Neu, T.R.; Molin, S.; Ullrich, M.S. Contribution of alginate and levan production to biofilm formation by Pseudomonas syringae. Microbiology 2006, 152, 2909-2918. [CrossRef] [PubMed]

80. Petruzzi, B.; Briggs, R.E.; Tatum, F.M.; Swords, W.E.; De Castro, C.; Molinaro, A.; Inzana, T.J. Capsular polysaccharide interferes with biofilm formation by Pasteurella multocida serogroup A. mBio 2017, 8, e01843-17. [CrossRef] [PubMed]

81. Singh, J.K.; Adams, F.G.; Brown, M.H. Diversity and function of capsular polysaccharide in Acinetobacter baumannii. Front. Microbiol. 2019, 9, 3301. [CrossRef] [PubMed]

82. Wyres, K.L.; Cahill, S.M.; Holt, K.E.; Hall, R.M.; Kenyon, J.J. Identification of Acinetobacter baumannii loci for capsular polysaccharide $(\mathrm{KL})$ and lipooligosaccharide outer core (OCL) synthesis in genome assemblies using curated reference databases compatible with Kaptive. Microb. Genom. 2020, 6, e000339. [CrossRef]

83. Qin, L.; Kida, Y.; Imamura, Y.; Kuwano, K.; Watanabe, H. Impaired capsular polysaccharide is relevant to enhanced biofilm formation and lower virulence in Streptococcus pneumoniae. J. Infect. Chemother. 2013, 19, 261-271. [CrossRef]

84. Lee, K.J.; Kim, J.A.; Hwang, W.; Park, S.J.; Lee, K.H. Role of capsular polysaccharide (CPS) in biofilm formation and regulation of CPS production by quorum-sensing in Vibrio vulnificus. Mol. Microbiol. 2013, 90, 841-857. [CrossRef]

85. Dogsa, I.; Brloznik, M.; Stopar, D.; Mandic-Mulec, I. Exopolymer diversity and the role of levan in Bacillus subtilis biofilms. PLoS ONE 2013, 8, e62044.

86. Koşarsoy Ağçeli, G.; Cihangir, N. Nano-sized biopolymer levan: Its antimicrobial, anti-biofilm and anti-cancer effects. Carbohydr. Res. 2020, 494, 108068. [CrossRef]

87. Hanna, A.; Berg, M.; Stout, V.; Razatos, A. Role of capsular colanic acid in adhesion of aropathogenic Escherichia coli. Appl. Environ. Microbiol. 2003, 69, 4474-4481. [CrossRef]

88. Sailer, F.C.; Meberg, B.M.; Young, K.D. beta-Lactam induction of colanic acid gene expression in Escherichia coli. FEMS Microbiol. Lett. 2003, 226, 245-249. [CrossRef]

89. Díaz-Pascual, F.; Hartmann, R.; Lempp, M.; Vidakovic, L.; Song, B.; Jeckel, H.; Thormann, K.M.; Yildiz, F.H.; Dunkel, J.; Link, H.; et al. Breakdown of Vibrio cholerae biofilm architecture induced by antibiotics disrupts community barrier function. Nat. Microbiol. 2019, 4, 2136-2145. [CrossRef] [PubMed]

90. Chen, P.; Wang, J.J.; Hong, B.; Tan, L.; Yan, J.; Zhang, Z.; Liu, H.; Pan, Y.; Zhao, Y. Characterization of mixed-species biofilm formed by Vibrio parahaemolyticus and Listeria monocytogenes. Front. Microbiol. 2019, 10, 2543. [CrossRef]

91. Yildiz, F.H.; Visick, K.L. Vibrio biofilms: So much the same yet so different. Trends Microbiol. 2009, 17, 109-118. [CrossRef] [PubMed]

92. Silva, A.J.; Benitez, J.A. Vibrio cholerae biofilms and cholera pathogenesis. PLoS Negl. Trop. Dis. 2016, 10, e0004330. [CrossRef] [PubMed]

93. Kernien, J.F.; Snarr, B.D.; Sheppard, D.C.; Nett, J.E. The Interface between fungal biofilms and innate immunity. Front. Immunol. 2018, 8, 1968. [CrossRef] [PubMed]

94. Xie, Z.; Thompson, A.; Sobue, T.; Kashleva, H.; Xu, H.; Vasilakos, J.; Dongari-Bagtzoglou, A. Candida albicans biofilms do not trigger reactive oxygen species and evade neutrophil killing. J. Infect. Dis. 2012, 206, 1936-1945. [CrossRef]

95. Bowen, W.H.; Koo, H. Biology of Streptococcus mutans-derived glucosyltransferases: Role in extracellular matrix formation of cariogenic biofilms. Caries Res. 2011, 45, 69-86. [CrossRef]

96. Rozen, R.; Bachrach, G.; Bronshteyn, M.; Gedalia, I.; Steinberg, D. The role of fructans on dental biofilm formation by Streptococcus sobrinus, Streptococcus mutans, Streptococcus gordonii and Actinomyces viscosus. FEMS Microbiol. Lett. 2001, 195, 205-210. [CrossRef]

97. Di Cagno, R.; De Angelis, M.; Limitone, A.; Minervini, F.; Carnevali, P.; Corsetti, A.; Gaenzle, M.; Ciati, R.; Gobbetti, M. Glucan and fructan production by sourdough Weissella cibaria and Lactobacillus plantarum. J. Agric. Food. Chem. 2006, 54,9873-9881. [CrossRef]

98. Lappin-Scott, H.M.; Bas, C. Biofilm formation: Attachment, growth, and detachment of microbes from surfaces. Am. J. Infect. Control 2001, 29, 250-251. [CrossRef] [PubMed]

99. Matilla, M.A. A technology for the investigation of biofilm transmission under shearing pressures. Microb. Biotechnol. 2017, 10, 1451-1453. [CrossRef]

100. Aparna, M.S.; Yadav, S. Biofilms: Microbes and disease. Braz. J. Infect. Dis. 2008, 12, 526-530. [CrossRef] [PubMed]

101. Otto, M. Staphylococcal infections: Mechanisms of biofilm maturation and detachment as critical determinants of pathogenicity. Annu. Rev. Med. 2013, 64, 175-188. [CrossRef] [PubMed]

102. Asadi, A.; Razavi, S.; Talebi, M.; Gholami, M. A review on anti-adhesion therapies of bacterial diseases. Infection 2019, 47, 13-23. [CrossRef] 
103. Ghilini, F.; Pissinis, D.E.; Miñán, A.; Schilardi, P.L.; Diaz, C. How functionalized surfaces can inhibit bacterial adhesion and viability. ACS Biomater. Sci. Eng. 2019, 5, 4920-4936. [CrossRef]

104. Rodrigues, L.R. Inhibition of bacterial adhesion on medical devices. Adv. Exp. Med. Biol. 2011, 715, $351-367$.

105. Pathak, R.; Bierman, S.F.; d'Arnaud, P. Inhibition of bacterial attachment and biofilm formation by a novel intravenous catheter material using an in vitro percutaneous catheter insertion model. Med. Devices Evid. Res. 2018, 11, 427-432. [CrossRef]

106. Tuson, H.H.; Weibel, D.B. Bacteria-surface interactions. Soft Matter 2013, 9, 4368-4380. [CrossRef]

107. Rizzo, C.; Zammuto, V.; Lo Giudice, A.; Rizzo, M.G.; Spanò, A.; Laganà, P.; Martinez, M.; Guglielmino, S.; Gugliandolo, C. Antibiofilm activity of antarctic sponge-associated bacteria against Pseudomonas aeruginosa and Staphylococcus aureus. J. Mar. Sci. Eng. 2021, 9, 243. [CrossRef]

108. Zammuto, V.; Rizzo, M.G.; Spanò, A.; Genovese, G.; Morabito, M.; Spagnuolo, D.; Capparucci, F.; Gervasi, C.; Smeriglio, A.; Trombetta, D.; et al. In vitro evaluation of antibiofilm activity of crude extracts from macroalgae against pathogens relevant in aquaculture. Aquaculture 2022, 549, 737729. [CrossRef]

109. Zheng, S.; Bawazir, M.; Dhall, A.; Kim, H.E.; He, L.; Heo, J.; Hwang, G. Implication of surface properties, bacterial motility, and hydrodynamic conditions on bacterial surface sensing and their initial adhesion. Front. Bioeng. Biotechnol. 2021, 9, 643722. [CrossRef] [PubMed]

110. Yadav, N.; Dubey, A.; Shukla, S.; Saini, C.P.; Gupta, G.; Priyadarshini, R.; Lochab, B. Graphene oxide-coated surface: Inhibition of bacterial biofilm formation due to specific surface-interface interactions. ACS Omega 2017, 2, 3070-3082. [CrossRef] [PubMed]

111. Trentin, D.S.; Silva, D.B.; Frasson, A.P.; Rzhepishevska, O.; da Silva, M.V.; Pulcini Ede, L.; James, G.; Soares, G.V.; Tasca, T.; Ramstedt, M.; et al. Natural green coating inhibits adhesion of clinically important bacteria. Sci. Rep. 2015, 5, 8287. [CrossRef]

112. Nagano-Takebe, F.; Miyakawa, H.; Nakazawa, F.; Endo, K. Inhibition of initial bacterial adhesion on titanium surfaces by lactoferrin coating. Biointerphases 2014, 9, 029006. [CrossRef]

113. Fleitas Martínez, O.; Rigueiras, P.O.; Pires, Á.D.S.; Porto, W.F.; Silva, O.N.; de la Fuente-Nunez, C.; Franco, O.L. Interference with quorum-sensing signal biosynthesis as a promising therapeutic strategy against multidrug-resistant pathogens. Front. Cell Infect. Microbiol. 2019, 8, 444. [CrossRef]

114. Reuter, K.; Steinbach, A.; Helms, V. Interfering with bacterial quorum sensing. Perspect. Med. Chem. 2016, 8, PMC-S13209. [CrossRef]

115. Wu, S.; Liu, C.; Feng, J.; Yang, A.; Guo, F.; Qiao, J. QSIdb: Quorum sensing interference molecules. Brief. Bioinform. 2021, 22, bbaa218. [CrossRef]

116. Jiang, Q.; Chen, J.; Yang, C.; Yin, Y.; Yao, K. Quorum sensing: A prospective therapeutic target for bacterial diseases. BioMed Res. Int. 2019, 2015978. [CrossRef]

117. Fong, J.; Zhang, C.; Yang, R.; Boo, Z.Z.; Tan, S.K.; Nielsen, T.E.; Givskov, M.; Liu, X.W.; Bin, W.; Su, H.; et al. Combination therapy strategy of quorum quenching enzyme and quorum sensing inhibitor in suppressing multiple quorum sensing pathways of $P$. aeruginosa. Sci. Rep. 2018, 8, 1155. [CrossRef]

118. Pereira, C.S.; Thompson, J.A.; Xavier, K.B. AI-2-mediated signalling in bacteria. FEMS Microbiol. Rev. 2013, 37, 156-181. [CrossRef] [PubMed]

119. Hemmati, F.; Salehi, R.; Ghotaslou, R.; Samadi Kafil, H.; Hasani, A.; Gholizadeh, P.; Nouri, R.; Ahangarzadeh Rezaee, M. Quorum quenching: A potential target for antipseudomonal therapy. Infect. Drug Resist. 2020, 13, 2989-3005. [CrossRef] [PubMed]

120. Seleem, N.M.; Abd El Latif, H.K.; Shaldam, M.A.; El-Ganiny, A. Drugs with new lease of life as quorum sensing inhibitors: For combating MDR Acinetobacter baumannii infections. Eur. J. Clin. Microbiol. Infect. Dis. 2020, 39, 1687-1702. [CrossRef] [PubMed]

121. Ng, W.-L.; Bassler, B.L. Bacterial quorum-sensing network architectures. Annu. Rev. Genet. 2009, 43, 197-222. [CrossRef] [PubMed]

122. Borges, A.; Simões, M. Quorum sensing inhibition by marine bacteria. Mar. Drugs 2019, 17, 427. [CrossRef]

123. Rasmussen, T.B.; Givskov, M. Quorum-sensing inhibitors as anti-pathogenic drugs. Int. J. Med. Microbiol. 2006, $296,149-161$. [CrossRef]

124. Dong, Y.-H.; Zhang, L.-H. Quorum sensing and quorum-quenching enzymes. J. Microbiol. Seoul Korea 2005, 43, 101-109.

125. Case, R.J.; Labbate, M.; Kjelleberg, S. AHL-driven quorum-sensing circuits: Their frequency and function among the Proteobacteria. ISME J. 2008, 2, 345-349. [CrossRef]

126. Steindler, L.; Venturi, V. Detection of quorum-sensing N-acyl homoserine lactone signal molecules by bacterial biosensors. FEMS Microbiol. Lett. 2007, 266, 1-9. [CrossRef]

127. Ling, J.; Zhou, L.; Wu, G.; Zhao, Y.; Jiang, T.; Liu, F. The AHL quorum-sensing system negatively regulates growth and autolysis in Lysobacter brunescens. Front. Microbiol. 2019, 10, 2748. [CrossRef]

128. Hengge, R.; Gründling, A.; Jenal, U.; Ryan, R.; Yildiz, F. Bacterial signal transduction by cyclic Di-GMP and other nucleotide second messengers. J. Bacteriol. 2015, 198, 15-26. [CrossRef] [PubMed]

129. Friebe, A.; Sandner, P.; Schmidtko, A. cGMP: A unique 2nd messenger molecule-Recent developments in cGMP research and development. Naunyn. Schmiedebergs Arch. Pharmacol. 2020, 393, 287-302. [CrossRef] [PubMed]

130. Newton, A.C.; Bootman, M.D.; Scott, J.D. Second Messengers. Cold Spring Harb. Perspect. Biol. 2016, 8, a005926. [CrossRef] [PubMed]

131. Yan, K.; Gao, L.-N.; Cui, Y.-L.; Zhang, Y.; Zhou, X. The cyclic AMP signaling pathway: Exploring targets for successful drug discovery (Review). Mol. Med. Rep. 2016, 13, 3715-3723. [CrossRef] [PubMed] 
132. Kariisa, A.T.; Grube, A.; Tamayo, R. Two nucleotide second messengers regulate the production of the Vibrio cholerae colonization factor GbpA. BMC Microbiol. 2015, 15, 166. [CrossRef]

133. Martín-Rodríguez, A.; Römling, U. Nucleotide second messenger signaling as a target for the control of bacterial biofilm formation Curr. Top. Med. Chem. 2017, 2017, 1928-1944. [CrossRef]

134. Thompson, C.M.; Malone, J.G. Nucleotide second messengers in bacterial decision making. Curr. Opin. Microbiol. $2020,55,34-39$. [CrossRef]

135. Moya-Beltrán, A.; Rojas-Villalobos, C.; Díaz, M.; Guiliani, N.; Quatrini, R.; Castro, M. Nucleotide second messenger-based signaling in extreme acidophiles of the Acidithiobacillus species complex: Partition between the core and variable gene complements. Front. Microbiol. 2019, 10, 381. [CrossRef]

136. Khoshnood, S.; Savari, M.; Montazeri, E.A.; Sheikh, A.F. Survey on genetic diversity, biofilm formation, and detection of colistin resistance genes in clinical isolates of Acinetobacter baumannii. Infect. Drug Resist. 2020, 13, 1547-1558. [CrossRef]

137. Malik, A.A.; Martiny, J.B.H.; Brodie, E.L.; Martiny, A.C.; Treseder, K.K.; Allison, S.D. Defining trait-based microbial strategies with consequences for soil carbon cycling under climate change. ISME J. 2020, 14, 1-9. [CrossRef]

138. Besharova, O.; Suchanek, V.M.; Hartmann, R.; Drescher, K.; Sourjik, V. Diversification of gene expression during formation of static submerged biofilms by Escherichia coli. Front. Microbiol. 2016, 7, 1568. [CrossRef] [PubMed]

139. Blazanin, M.; Turner, P.E. Community context matters for bacteria-phage ecology and evolution. ISME J. 2021, 15, 3119-3128. [CrossRef]

140. Kaplan, J.B. Biofilm dispersal. J. Dent. Res. 2010, 89, 205-218. [CrossRef] [PubMed]

141. Guilhen, C.; Forestier, C.; Balestrino, D. Biofilm dispersal: Multiple elaborate strategies for dissemination of bacteria with unique properties. Mol. Microbiol. 2017, 105, 188-210. [CrossRef] [PubMed]

142. Wille, J.; Coenye, T. Biofilm dispersion: The key to biofilm eradication or opening Pandora's box? Biofilm 2020, $2,100027$. [CrossRef] [PubMed]

143. Boles, B.R.; Horswill, A.R. agr-Mediated dispersal of Staphylococcus aureus biofilms. PLoS Pathog. 2008, 4, e1000052. [CrossRef]

144. Stewart, P.S. Mechanisms of antibiotic resistance in bacterial biofilms. Int. J. Med. Microbiol. 2002, 292, 107-113. [CrossRef]

145. Mah, T.-F.C.; O’Toole, G.A. Mechanisms of biofilm resistance to antimicrobial agents. Trends Microbiol. 2001, 9, 34-39. [CrossRef]

146. Fleitas Martínez, O.; Cardoso, M.H.; Ribeiro, S.M.; Franco, O.L. Recent advances in anti-virulence therapeutic strategies with a focus on dismantling bacterial membrane microdomains, toxin neutralization, quorum-sensing interference and biofilm inhibition. Front. Cell. Infect. Microbiol. 2019, 9, 74. [CrossRef]

147. Cepas, V.; López, Y.; Muñoz, E.; Rolo, D.; Ardanuy, C.; Martí, S.; Xercavins, M.; Horcajada, J.P.; Bosch, J.; Soto, S.M. Relationship between biofilm formation and antimicrobial resistance in Gram-negative bacteria. Microb. Drug Resist. 2019, 25, 72-79. [CrossRef]

148. Ahmad, I.; Nawaz, N.; Dermani, F.K.; Kohlan, A.K.; Saidijam, M.; Patching, S.G. Bacterial multidrug efflux proteins: A major mechanism of antimicrobial resistance. Curr. Drug Targets 2018, 19, 1-13. [CrossRef]

149. Tu, C.; Wang, Y.; Yi, L.; Wang, Y.; Liu, B.; Gong, S. Roles of signaling molecules in biofilm formation. Sheng Wu Gong Cheng Xue Bao Chin. J. Biotechnol. 2019, 35, 558-566.

150. Shrout, J.D.; Tolker-Nielsen, T.; Givskov, M.; Parsek, M.R. The contribution of cell-cell signaling and motility to bacterial biofilm formation. MRS Bull. 2011, 36, 367-373. [CrossRef] [PubMed]

151. Abebe, G.M. The role of bacterial biofilm in antibiotic resistance and food contamination. Int. J. Microbiol. 2020, 2020, e1705814. [CrossRef]

152. Davies, D. Understanding biofilm resistance to antibacterial agents. Nat. Rev. Drug Discov. 2003, 2, 114-122. [CrossRef]

153. Yan, Z.; Huang, M.; Melander, C.; Kjellerup, B.V. Dispersal and inhibition of biofilms associated with infections. J. Appl. Microbiol. 2020, 128, 1279-1288. [CrossRef]

154. Tkachenko, A.; Kashevarova, N.M.; Sidorov, R.Y.; Nesterova, L.Y.; Akhova, A.V.; Tsyganov, I.V.; Vaganov, V.Y.; Shipilovskikh, S.A.; Rubtsov, A.E.; Malkov, A.V. A Novel Synthetic Diterpene Reduces Mycobacterial Persistence and Biofilm Formation by Targeting (p)ppGpp Synthetases; SSRN Scholarly Paper ID 3696759; Social Science Research Network: Rochester, NY, USA, 2020. [CrossRef]

155. Tkachenko, A.G.; Kashevarova, N.M.; Sidorov, R.Y.; Nesterova, L.Y.; Akhova, A.V.; Tsyganov, I.V.; Vaganov, V.Y.; Shipilovskikh S.A.; Rubtsov, A.E.; Malkov, A.V. A synthetic diterpene analogue inhibits mycobacterial persistence and biofilm formation by targeting (p)ppGpp synthetases. Cell Chem. Biol. 2021, 28, 1420-1432. [CrossRef]

156. Parrino, B.; Carbone, D.; Cascioferro, S.; Pecoraro, C.; Giovannetti, E.; Deng, D.; Di Sarno, V.; Musella, S.; Auriemma, G.; Cusimano, M.G.; et al. 1,2,4-Oxadiazole topsentin analogs as staphylococcal biofilm inhibitors targeting the bacterial transpeptidase sortase A. Eur. J. Med. Chem. 2021, 209, 112892. [CrossRef]

157. Carbone, A.; Cascioferro, S.; Parrino, B.; Carbone, D.; Pecoraro, C.; Schillaci, D.; Cusimano, M.G.; Cirrincione, G.; Diana, P. Thiazole analogues of the marine alkaloid nortopsentin as inhibitors of bacterial biofilm formation. Molecules 2021, $26,81$. [CrossRef]

158. El-Messery, S.M.; Habib, E.-S.E.; Al-Rashood, S.T.A.; Hassan, G.S. Synthesis, antimicrobial, anti-biofilm evaluation, and molecular modelling study of new chalcone linked amines derivatives. J. Enzyme Inhib. Med. Chem. 2018, 33, 818-832. [CrossRef]

159. Kant, R.; Kumarm, D.; Agarwal, D.; Gupta, R.D.; Tilak, R.; Awasthi, S.K.; Agarwal, A. Synthesis of newer 1,2,3-triazole linked chalcone and flavone hybrid compounds and evaluation of their antimicrobial and cytotoxic activities. Eur. J. Med. Chem. 2016, 113, 34-49. [CrossRef] [PubMed] 
160. Xu, X.-J.; Zeng, T.; Huang, Z.-X.; Xu, X.-F.; Lin, J.; Chen, W.-M. Synthesis and biological evaluation of cajaninstilbene acid and amorfrutins A and B as inhibitors of the Pseudomonas aeruginosa quorum sensing system. J. Nat. Prod. 2018, 81, 2621-2629. [CrossRef] [PubMed]

161. Huang, Z.-X.; Yu, J.-H.; Xu, X.-J.; Xu, X.-F.; Zeng, T.; Lin, J.; Chen, W.-M. Cajaninstilbene acid analogues as novel quorum sensing and biofilm inhibitors of Pseudomonas aeruginosa. Microb. Pathog. 2020, 148, 104414. [CrossRef] [PubMed]

162. Algburi, A.; Zehm, S.; Netrebov, V.; Bren, A.B.; Chistyakov, V.; Chikindas, M.L. Subtilosin prevents biofilm formation by inhibiting bacterial quorum sensing. Probiotics Antimicrob. Proteins 2017, 9, 81-90. [CrossRef]

163. Zhou, J.-W.; Luo, H.-Z.; Jiang, H.; Jian, T.-K.; Chen, Z.-Q.; Jia, A.-Q. Hordenine: A novel quorum sensing inhibitor and antibiofilm agent against Pseudomonas aeruginosa. J. Agric. Food Chem. 2018, 66, 1620-1628. [CrossRef]

164. Zhao, C.; Zheng, H.; Zhou, L.; Ji, H.; Zhao, L.; Yu, W.; Gong, Q. Falcarindiol isolated from Notopterygium incisum inhibits the quorum sensing of Pseudomonas aeruginosa. Molecules 2021, 26, 5896. [CrossRef]

165. Liu, Y.; Li, J.-J.; Li, H.-Y.; Deng, S.-M.; Jia, A.-Q. Quorum sensing inhibition of hordenine analogs on Pseudomonas aeruginosa and Serratia marcescens. Synth. Syst. Biotechnol. 2021, 6, 360-368. [CrossRef]

166. Ganguly, K.; Wu, R.; Ollivault-Shiflett, M.; Goodwin, P.M.; Silks, L.A.; Iyer, R. Design, synthesis, and a novel application of quorum-sensing agonists as potential drug-delivery vehicles. J. Drug Target. 2011, 19, 528-539. [CrossRef]

167. Heinonen, T.; Hargraves, S.; Georgieva, M.; Widmann, C.; Jacquier, N. The antimicrobial peptide TAT-RasGAP317-326 inhibits the formation and expansion of bacterial biofilms in vitro. J. Glob. Antimicrob. Resist. 2021, 25, 227-231. [CrossRef]

168. Lin, B.; Li, R.; Handley, T.N.G.; Wade, J.D.; Li, W.; O’Brien-Simpson, N.M. Cationic antimicrobial peptides are leading the way to combat oropathogenic infections. ACS Infect. Dis. 2021, 7, 2959-2970. [CrossRef]

169. Wuersching, S.N.; Huth, K.C.; Hickel, R.; Kollmuss, M. Inhibitory effect of LL-37 and human lactoferricin on growth and biofilm formation of anaerobes associated with oral diseases. Anaerobe 2021, 67, 102301. [CrossRef] [PubMed]

170. Ciandrini, E.; Morroni, G.; Cirioni, O.; Kamysz, W.; Kamysz, E.; Brescini, L.; Baffone, W.; Campana, R. Synergistic combinations of antimicrobial peptides against biofilms of methicillin-resistant Staphylococcus aureus (MRSA) on polystyrene and medical devices. J. Glob. Antimicrob. Resist. 2020, 21, 203-210. [CrossRef] [PubMed]

171. Ciandrin, E.; Morroni, G.; Arzeni, D.; Kamysz, W.; Neubauer, D.; Kamysz, E.; Cirioni, O.; Brescini, L.; Baffone, W.; Campana, R. Antimicrobial activity of different antimicrobial peptides (AMPs) against clinical methicillin-resistant Staphylococcus aureus (MRSA). Curr. Top. Med. Chem. 2018, 18, 2116-2126. [CrossRef] [PubMed]

172. Festa, R.; Ambrosio, R.L.; Lamas, A.; Gratino, L.; Palmieri, G.; Franco, C.M.; Cepeda, A.; Anastasio, A. A study on the antimicrobial and antibiofilm peptide 1018-K6 as potential alternative to antibiotics against food-pathogen Salmonella enterica. Foods 2021, 10, 1372. [CrossRef]

173. Colagiorgi, A.; Festa, R.; Di Ciccio, P.A.; Gogliettino, M.; Balestrieri, M.; Palmieri, G.; Anastasio, A.; Ianieri, A. Rapid biofilm eradication of the antimicrobial peptide 1018-K6 against Staphylococcus aureus: A new potential tool to fight bacterial biofilms. Food Control 2020, 107, 106815. [CrossRef]

174. Ozturk, B.; Gunay, N.; Ertugrul, B.M.; Sakarya, S. Effects of vancomycin, daptomycin, and tigecycline on coagulase-negative staphylococcus biofilm and bacterial viability within biofilm: An in vitro biofilm model. Can. J. Microbiol. 2016, 62, 735-743. [CrossRef]

175. Epand, R.M.; Walker, C.; Epand, R.F.; Magarvey, N.A. Molecular mechanisms of membrane targeting antibiotics. Biochim. Biophys. Acta 2016, 1858, 980-987. [CrossRef]

176. Angelopoulou, A.; Field, D.; Pérez-Ibarreche, M.; Warda, A.K.; Hill, C.; Ross, R.P. Vancomycin and nisin A are effective against biofilms of multi-drug resistant Staphylococcus aureus isolates from human milk. PLoS ONE 2020, 15, e0233284. [CrossRef]

177. Lima, M.R.; Ferreira, G.F.; Nunes Neto, W.R.; Monteiro, J.M.; Santos, Á.R.C.; Tavares, P.B.; Denadai, Â.M.L.; Bomfim, M.R.Q.; Dos Santos, V.L.; Marques, S.G.; et al. Evaluation of the interaction between polymyxin B and Pseudomonas aeruginosa biofilm and planktonic cells: Reactive oxygen species induction and zeta potential. BMC Microbiol. 2019, 19, 115. [CrossRef]

178. Fernandes, L.; Fortes, B.N.; Lincopan, N.; Ishida, K. Caspofungin and polymyxin B reduce the cell viability and total biomass of mixed biofilms of carbapenem-resistant Pseudomonas aeruginosa and Candida spp. Front. Microbiol. 2020, 11, 573263. [CrossRef]

179. Wang, Y.; Venter, H.; Ma, S. Efflux pump inhibitors: A novel approach to combat efflux-mediated drug resistance in bacteria. Curr. Drug Targets 2016, 17, 702-719. [CrossRef] [PubMed]

180. Zimmermann, S.; Klinger-Strobel, M.; Bohnert, J.A.; Wendler, S.; Rödel, J.; Pletz, M.W.; Löffler, B.; Tuchscherr, L. Clinically approved drugs inhibit the Staphylococcus aureus multidrug NorA efflux pump and reduce biofilm formation. Front. Microbiol. 2019, 10, 2762. [CrossRef] [PubMed]

181. Xu, X.; Hazra, S.; Blanchard, J.S. NXL104 irreversibly inhibits the $\beta$-lactamase from Mycobacterium tuberculosis. Biochemistry 2012, 51, 4551-4557. [CrossRef] [PubMed]

182. Sharma, R.; Park, T.E.; Moy, S. Ceftazidime-avibactam: A novel cephalosporin/ $\beta$-lactamase inhibitor combination for the treatment of resistant Gram-negative organisms. Clin. Ther. 2016, 38, 431-444. [CrossRef] [PubMed]

183. Allen, N.E.; Alborn, W.E.; Hobbs, J.N.; Kirst, H.A. 7-Hydroxytropolone: An inhibitor of aminoglycoside-2"-O-adenylyltransferase. Antimicrob. Agents Chemother. 1982, 22, 824-831. [CrossRef] [PubMed]

184. Cox, G.; Ejim, L.; Stogios, P.J.; Koteva, K.; Bordeleau, E.; Evdokimova, E.; Sieron, A.O.; Savchenko, A.; Serio, A.W.; Krause, K.M.; et al. Plazomicin retains antibiotic activity against most aminoglycoside modifying enzymes. ACS Infect. Dis. 2018, 4, 980-987. [CrossRef] 
185. Karaiskos, I.; Lagou, S.; Pontikis, K.; Rapti, V.; Poulakou, G. The 'old' and the 'new' antibiotics for MDR Gram-negative pathogens: For whom, when, and how. Front. Public Health 2019, 7, 151. [CrossRef]

186. Spengler, G.; Kincses, A.; Gajdács, M.; Amaral, L. New roads leading to old destinations: Efflux pumps as targets to reverse multidrug resistance in bacteria. Molecules 2017, 22, 468. [CrossRef]

187. Reza, A.; Sutton, J.M.; Rahman, K.M. Effectiveness of efflux pump inhibitors as biofilm disruptors and resistance breakers in Gram-negative (ESKAPEE) bacteria. Antibiotics 2019, 8, 229. [CrossRef]

188. Bhattacharyya, T.; Sharma, A.; Akhter, J.; Pathania, R. The small molecule IITR08027 restores the antibacterial activity of fluoroquinolones against multidrug-resistant Acinetobacter baumannii by efflux inhibition. Int. J. Antimicrob. Agents 2017, 50, 219-226. [CrossRef]

189. Vargiu, A.V.; Ruggerone, P.; Opperman, T.J.; Nguyen, S.T.; Nikaido, H. Molecular mechanism of MBX2319 inhibition of Escherichia coli AcrB multidrug efflux pump and comparison with other inhibitors. Antimicrob. Agents Chemother. 2014, 58, 6224-6234. [CrossRef]

190. Kumar Tiwari, S.; Guo, X.; Huang, Y.; Zhou, X.; Xu, H.H.K.; Ren, B.; Peng, X.; Weir, M.D.; Li, M.; Cheng, L. The inhibitory effect of quaternary ammonium salt on bacteria in root canal. Sci. Rep. 2019, 9, 12463. [CrossRef]

191. Daood, U.; Burrow, M.F.; Yiu, C.K.Y. Effect of a novel quaternary ammonium silane cavity disinfectant on cariogenic biofilm formation. Clin. Oral Investig. 2020, 24, 649-661. [CrossRef]

192. Butler, M.S.; Blaskovich, M.A.; Cooper, M.A. Antibiotics in the clinical pipeline at the end of 2015. J. Antibiot. 2017, 70, 324. [CrossRef]

193. Ooi, N.; Miller, K.; Randall, C.; Rhys-Williams, W.; Love, W.; Chopra, I. XF-70 and XF-73, novel antibacterial agents active against slow-growing and non-dividing cultures of Staphylococcus aureus including biofilms. J. Antimicrob. Chemother. 2010, 65, 72-78. [CrossRef]

194. Butler, M.S.; Paterson, D.L. Antibiotics in the clinical pipeline in October 2019. J. Antibiot. 2020, 73, 329-364. [CrossRef]

195. Murakami, K.; Yumoto, H.; Murakami, A.; Amoh, T.; Viducic, D.; Hirota, K.; Tabata, A.; Nagamune, H.; Kourai, H.; Matsuo, T.; et al. Evaluation of the effectiveness of the potent bis-quaternary ammonium compound, $4,4^{\prime}-(\alpha, \omega$-hexametylenedithio) bis (1-octylpyridinium bromide) (4DTBP-6,8) on Pseudomonas aeruginosa. J. Appl. Microbiol. 2017, 122, 893-899. [CrossRef]

196. Dong, J.; Zhang, L.; Liu, Y.; Zhou, S.; Yang, Y.; Xu, N.; Yang, Q.; Ai, X. Resveratrol influences the pathogenesis of Aeromonas hydrophila by inhibiting production of aerolysin and biofilm. Food Control 2021, 126, 108083. [CrossRef]

197. Oh, H.S.; Yeon, K.M.; Yang, C.S.; Kim, S.R.; Lee, C.H.; Park, S.Y.; Han, J.Y.; Lee, J.K. Control of membrane biofouling in MBR for wastewater treatment by quorum quenching bacteria encapsulated in microporous membrane. Environ. Sci. Technol. 2012, 46, 4877-4884. [CrossRef]

198. Husain, F.M.; Perveen, K.; Qais, F.A.; Ahmad, I.; Alfarhan, A.H.; El-Sheikh, M.A. Naringin inhibits the biofilms of metallo- $\beta$ lactamases $(\mathrm{M} \beta \mathrm{Ls})$ producing Pseudomonas species isolated from camel meat. Saudi J. Biol. Sci. 2021, 28, 333-341. [CrossRef]

199. Lyu, X.; Wang, L.; Shui, Y.; Jiang, Q.; Chen, L.; Yang, W.; He, X.; Zeng, J.; Li, Y. Ursolic acid inhibits multi-species biofilms developed by Streptococcus mutans, Streptococcus sanguinis, and Streptococcus gordonii. Arch. Oral Biol. 2021, 125, 105107. [CrossRef]

200. Wei, L.N.; Shi, C.; Luo, C.; Hu, C.; Meng, Y. Phloretin inhibits biofilm formation by affecting quorum sensing under different temperature. Lebensmittel-Wissenschaft und-Technologie 2020, 131, 109668. [CrossRef]

201. Pun, M.; Khazanov, N.; Galsurker, O.; Weitman, M.; Kerem, Z.; Senderowitz, H.; Yedidia, I. Phloretin, an apple phytoalexin, affects the virulence and fitness of Pectobacterium brasiliense by interfering with quorum-sensing. Front. Plant Sci. 2021, 12, 671807. [CrossRef]

202. Wang, J.; Jiao, H.; Meng, J.; Qiao, M.; Du, H.; He, M.; Ming, K.; Liu, J.; Wang, D.; Wu, Y. Baicalin inhibits biofilm formation and the quorum-sensing system by regulating the MsrA drug efflux pump in Staphylococcus saprophyticus. Front. Microbiol. 2019, 10, 2800. [CrossRef]

203. Ozma, M.A.; Khodadadi, E.; Pakdel, F.; Kamounah, F.S.; Yousefi, M.; Yousefi, B.; Asgharzadeh, M.; Ganbarov, K.; Kafil, H. Baicalin, a natural antimicrobial and anti-biofilm agent. J. Herb. Med. 2021, 27, 100432. [CrossRef]

204. Reis, S.V.D.; Couto, N.M.G.; Brust, F.R.; Trentin, D.S.; Silva, J.K.R.D.; Arruda, M.S.P.; Gnoatto, S.C.; Macedo, A.J. Remarkable capacity of brosimine b to disrupt methicillin-resistant Staphylococcus aureus (MRSA) preformed biofilms. Microb. Pathog. 2020, 140, 103967. [CrossRef]

205. Nikinmaa, S.; Alapulli, H.; Auvinen, P.; Vaara, M.; Rantala, J.; Kankuri, E.; Sorsa, T.; Meurman, J.; Pätilä, T. Dual-light photodynamic therapy administered daily provides a sustained antibacterial effect on biofilm and prevents Streptococcus mutans adaptation. PLoS ONE 2020, 15, e0232775. [CrossRef]

206. Kawczyk-Krupka, A.; Pucelik, B.; Międzybrodzka, A.; Sieroń, A.R.; Dąbrowski, J.M. Photodynamic therapy as an alternative to antibiotic therapy for the treatment of infected leg ulcers. Photodiagnosis Photodyn. Ther. 2018, 23, 132-143. [CrossRef]

207. Warrier, A.; Mazumder, N.; Prabhu, S.; Satyamoorthy, K.; Murali, T.S. Photodynamic therapy to control microbial biofilms. Photodiagnosis Photodyn. Ther. 2021, 33, 102090. [CrossRef]

208. Ronqui, M.R.; de Aguiar Coletti, T.M.S.F.; de Freitas, L.M.; Miranda, E.T.; Fontana, C.R. Synergistic antimicrobial effect of photodynamic therapy and ciprofloxacin. J. Photochem. Photobiol. B 2016, 158, 122-129. [CrossRef]

209. Clift, C.; Salisbury, D.M. Enhancing the role of vaccines in combatting antimicrobial resistance. Vaccine 2017, 35, 6591-6593. [CrossRef] 
210. Micoli, F.; Bagnoli, F.; Rappuoli, R.; Serruto, D. The role of vaccines in combatting antimicrobial resistance. Nat. Rev. Microbiol. 2021, 19, 287-302. [CrossRef]

211. Levites, Y.; O’Nuallain, B.; Puligedda, R.D.; Ondrejcak, T.; Adekar, S.P.; Chen, C.; Cruz, P.E.; Rosario, A.M.; Macy, S.; Mably, A.J.; et al. A human monoclonal IgG that binds a $\beta$ assemblies and diverse amyloids exhibits anti-amyloid activities in vitro and in vivo. J. Neurosci. 2015, 35, 6265-6276. [CrossRef]

212. Matilla-Cuenca, L.; Toledo-Arana, A.; Valle, J. Anti-biofilm molecules targeting functional amyloids. Antibiotics 2021, 10, 795. [CrossRef]

213. Tursi, S.A.; Puligedda, R.D.; Szabo, P.; Nicastro, L.K.; Miller, A.L.; Qiu, C.; Gallucci, S.; Relkin, N.R.; Buttaro, B.A.; Dessain, S.K.; et al. Salmonella Typhimurium biofilm disruption by a human antibody that binds a pan-amyloid epitope on curli. Nat. Commun. 2020, 11, 1007. [CrossRef]

214. de Vor, L.; van Dijk, B.; van Kessel, K.P.M.; Kavanaugh, J.S.; de Haas, K.J.C.; Aerts, P.C.; Viveen, M.C.; Boel, E.C.H.; Fluit, A.C.; Kwiecinski, J.M.; et al. Human monoclonal antibodies against Staphylococcus aureus surface antigens recognize in vitro biofilm and in vivo implant infections. bioRxiv 2021. [CrossRef]

215. Sun, D.; Accavitti, M.A.; Bryers, J.D. Inhibition of biofilm formation by monoclonal antibodies against Staphylococcus epidermidis RP62A accumulation-associated protein. Clin. Diagn. Lab. Immunol. 2005, 12, 93-100. [CrossRef]

216. Melo, L.D.; Veiga, P.; Cerca, N.; Kropinski, A.M.; Almeida, C.; Azeredo, J.; Sillankorva, S. Development of a phage cocktail to control Proteus mirabilis catheter-associated urinary tract infections. Front. Microbiol. 2016, 7, 1024. [CrossRef]

217. Maurice, N.M.; Bedi, B.; Sadikot, R.T. Pseudomonas aeruginosa biofilms: Host response and clinical implications in lung infections. Am. J. Respir. Cell Mol. Biol. 2018, 58, 428-439. [CrossRef]

218. Walsh, L.; Johnson, C.N.; Hill, C.; Ross, R.P. Efficacy of phage- and bacteriocin-based therapies in combatting nosocomial MRSA infections. Front. Mol. Biosci. 2021, 8, 654038. [CrossRef]

219. Sharma, U.; Paul, V.D. Bacteriophage lysins as antibacterials. Crit. Care 2017, 21, 99. [CrossRef]

220. Watson, A.; Oh, J.T.; Sauve, K.; Bradford, P.A.; Cassino, C.; Schuch, R. Antimicrobial activity of exebacase (Lysin CF-301) against the most common causes of infective endocarditis. Antimicrob. Agents Chemother. 2019, 63, e01078-19. [CrossRef]

221. Jaggessar, A.; Shahali, H.; Mathew, A.; Yarlagadda, P.K.D.V. Bio-mimicking nano and micro-structured surface fabrication for antibacterial properties in medical implants. J. Nanobiotechnol. 2017, 15, 64. [CrossRef]

222. Wood, M.A. Colloidal lithography and current fabrication techniques producing in-plane nanotopography for biological applications. J. R. Soc. Interface 2007, 4, 1-17. [CrossRef]

223. Shahid, A.; Aslam, B.; Muzammil, S.; Aslam, N.; Shahid, M.; Almatroudi, A.; Allemailem, K.S.; Saqalein, M.; Nisar, M.A.; Rasool, M.H.; et al. The prospects of antimicrobial coated medical implants. J. Appl. Biomater. Funct. Mater. 2021, 19, 22808000211040304. [CrossRef]

224. Adlhart, C.; Verran, J.; Azevedo, N.F.; Olmez, H.; Keinänen-Toivola, M.M.; Gouveia, I.; Melo, L.F.; Crijns, F. Surface modifications for antimicrobial effects in the healthcare setting: A critical overview. J. Hosp. Infect. 2018, 99, 239-249. [CrossRef]

225. Sakala, G.P.; Reches, M. Peptide-based approaches to fight biofouling. Adv. Mater. Interfaces 2018, 5, 1800073. [CrossRef]

226. Hage, M.; Akoum, H.; Chihib, N.-E.; Jama, C. Antimicrobial peptides-coated stainless steel for fighting biofilms formation for food and medical fields: Review of literature. Coatings 2021, 11, 1216. [CrossRef]

227. Ivanova, K.; Fernandes, M.M.; Mendoza, E.; Tzanov, T. Enzyme multilayer coatings inhibit Pseudomonas aeruginosa biofilm formation on urinary catheters. Appl. Microbiol. Biotechnol. 2015, 99, 4373-4385. [CrossRef]

228. Ivanova, A.; Ivanova, K.; Tied, A.; Heinze, T.; Tzanov, T. Layer-by-layer coating of aminocellulose and quorum quenching acylase on silver nanoparticles synergistically eradicate bacteria and their biofilms. Adv. Funct. Mater. 2020, 30, 2001284. [CrossRef]

229. Rose, W.E.; Otto, D.P.; Aucamp, M.E.; Miller, Z.; de Villiers, M.M. Prevention of biofilm formation by methacrylate-based copolymer films loaded with rifampin, clarithromycin, doxycycline alone or in combination. Pharm. Res. 2015, 32, 61-73. [CrossRef]

230. Ashbaugh, A.G.; Jiang, X.; Zheng, J.; Tsai, A.S.; Kim, W.S.; Thompson, J.M.; Miller, R.J.; Shahbazian, J.H.; Wang, Y.; Dillen, C.A.; et al. Polymeric nanofiber coating with tunable combinatorial antibiotic delivery prevents biofilm-associated infection in vivo. Proc. Natl. Acad. Sci. USA 2016, 113, E6919-E6928. [CrossRef]

231. Siddique, M.H.; Aslam, B.; Imran, M.; Ashraf, A.; Nadeem, H.; Hayat, S.; Khurshid, M.; Afzal, M.; Malik, I.R.; Shahzad, M.; et al. Effect of silver nanoparticles on biofilm formation and EPS production of multidrug-resistant Klebsiella pneumoniae. Biomed. Res. Int. 2020, 2020, 6398165. [CrossRef]

232. Hetta, H.F.; Al-Kadmy, I.M.S.; Khazaal, S.S.; Abbas, S.; Suhail, A.; El-Mokhtar, M.A.; Ellah, N.H.A.; Ahmed, E.A.; Abd-Ellatief, R.B.; El-Masry, E.A.; et al. Antibiofilm and antivirulence potential of silver nanoparticles against multidrug-resistant Acinetobacter baumannii. Sci. Rep. 2021, 11, 10751. [CrossRef]

233. Singh, P.; Pandit, S.; Garnæs, J.; Tunjic, S.; Mokkapati, V.R.; Sultan, A.; Thygesen, A.; Mackevica, A.; Mateiu, R.V.; Daugaard, A.E.; et al. Green synthesis of gold and silver nanoparticles from Cannabis sativa (industrial hemp) and their capacity for biofilm inhibition. Int. J. Nanomed. 2018, 13, 3571-3591. [CrossRef]

234. Gounani, Z.; Asadollahi, M.A.; Pedersen, J.N.; Lyngsø, J.; Skov Pedersen, J.; Arpanaei, A.; Meyer, R.L. Mesoporous silica nanoparticles carrying multiple antibiotics provide enhanced synergistic effect and improved biocompatibility. Colloids Surf. $B$ Biointerfaces 2019, 175, 498-508. [CrossRef] 
235. Ivashchenko, O.; Peplińska, B.; Gapiński, J.; Flak, D.; Jarek, M.; Załęski, K.; Nowaczyk, G.; Pietralik, Z.; Jurga, S. Silver and ultrasmall iron oxides nanoparticles in hydrocolloids: Effect of magnetic field and temperature on self-organization. Sci. Rep. 2018, 8, 4041. [CrossRef]

236. Sangili, A.; Annalakshmi, M.; Chen, S.-M.; Balasubramanian, P.; Sundrarajan, M. Synthesis of silver nanoparticles decorated on core-shell structured tannic acid-coated iron oxide nanospheres for excellent electrochemical detection and efficient catalytic reduction of hazardous 4-nitrophenol. Compos. Part B Eng. 2019, 162, 33-42. [CrossRef]

237. Kabachii, Y.A.; Golub, A.S.; Kochev, S.Y.; Lenenko, N.D.; Abramchuk, S.S.; Antipin, M.Y.; Valetsky, P.M.; Stein, B.D.; Mahmoud, W.E.; Al-Ghamdi, A.A.; et al. Multifunctional nanohybrids by self-assembly of monodisperse iron oxide nanoparticles and nanolamellar $\mathrm{MoS}_{2}$ plates. Chem. Mater. 2013, 25, 2434-2440. [CrossRef]

238. Abenojar, E.C.; Wickramasinghe, S.; Ju, M.; Uppaluri, S.; Klika, A.; George, J.; Barsoum, W.; Frangiamore, S.J.; Higuera-Rueda, C.A.; Samia, A.C.S. Magnetic glycol chitin-based hydrogel nanocomposite for combined thermal and d-amino-acid-assisted biofilm disruption. ACS Infect. Dis. 2018, 4, 1246-1256. [CrossRef]

239. Kolodkin-Gal, I.; Romero, D.; Cao, S.; Clardy, J.; Kolter, R.; Losick, R. D-Amino acids trigger biofilm disassembly. Science 2010, 328, 627-629. [CrossRef]

240. Lahiri, D.; Nag, M.; Sheikh, H.I.; Sarkar, T.; Edinur, H.A.; Pati, S.; Ray, R.R. Microbiologically-synthesized nanoparticles and their role in silencing the biofilm signaling cascade. Front. Microbiol. 2021, 12, 636588. [CrossRef]

241. Wang, L.; Hu, C.; Shao, L. The antimicrobial activity of nanoparticles: Present situation and prospects for the future. Int. J. Nanomed. 2017, 12, 1227-1249. [CrossRef] 